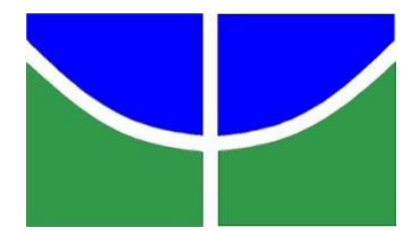

UNIVERSIDADE DE BRASÍLIA

Faculdade de Agronomia e Medicina Veterinária

Programa de Pós-graduação em Saúde Animal

\title{
PREVALÊNCIA E FATORES DE RISCO DA TUBERCULOSE BOVINA NO DISTRITO FEDERAL, BRASIL, 2015
}

GERALDO TEIXEIRA DO NASCIMENTO

DISSERTAÇÃO DE MESTRADO EM SAÚDE ANIMAL

BRASÍLIA/DF

DEZEMBRO/2016 


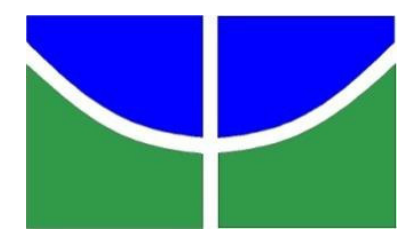

UNIVERSIDADE DE BRASÍLIA

Faculdade de Agronomia e Medicina Veterinária

Programa de Pós-graduação em Saúde Animal

\section{PREVALENCIA E FATORES DE RISCO DA TUBERCULOSE BOVINA NO DISTRITO FEDERAL, BRASIL, 2015}

\section{GERALDO TEIXEIRA DO NASCIMENTO}

ORIENTADOR: Prof. Dr. VÍTOR SALVADOR PICÃO GONÇALVES

$$
\text { PUBLICAÇÃ̃O No 133/2016 }
$$

DISSERTAÇÃO DE MESTRADO EM SAÚDE ANIMAL ÁREA DE CONCENTRAÇÃO: MEDICINA PREVENTIVA E PATOLOGIA VETERINÁRIA LINHA DE PESQUISA: EPIDEMIOLOGIA, PREVENÇÃO E CONTROLE DE DOENÇAS DOS ANIMAIS E GESTÃO DOS RISCOS PARA A SAÚDE PÚBLICA

BRASÍLIA/DF

DEZEMBRO/2016 


\title{
PREVALÊNCIA E FATORES DE RISCO DA TUBERCULOSE BOVINA NO DISTRITO FEDERAL, BRASIL, 2015.
}

\author{
GERALDO TEIXEIRA DO NASCIMENTO
}

DISSERTAÇ̃̃O DE MESTRADO SUBMETIDA AO PROGRAMA DE PÓSGRADUAÇÃO EM SAÚDE ANIMAL, COMO PARTE DOS REQUISITOS NECESSÁRIOS À OBTENÇÃO DO GRAU DE MESTRE EM SAÚDE ANIMAL.

APROVADA POR:

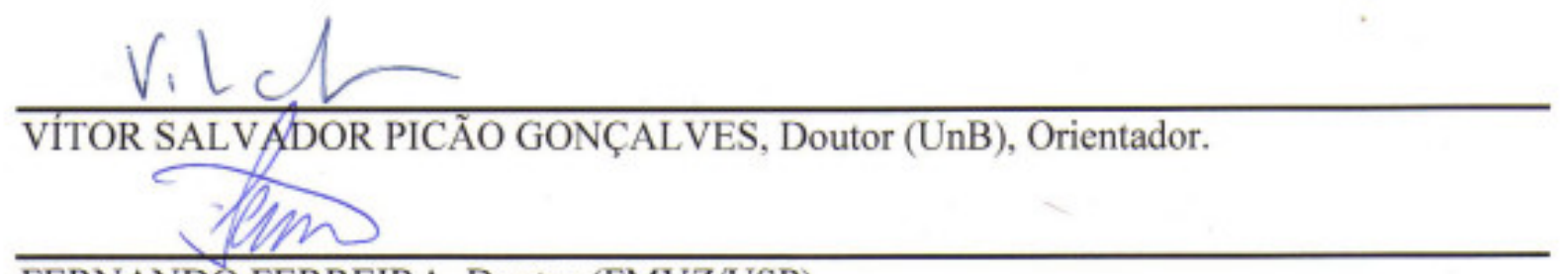

FERNANDO FERREIRA, Doutor (FMVZ/USP).

$\frac{\text { Whacs Payor Haine en }}{\text { MARCOS BRYAN HEINEMANN, Doutor (FMVZ/USP) }}$

BRASÍLIA, DF, 09 DE DEZEMBRO DE 2016. 


\section{REFERÊNCIA BIBLIOGRÁFICA E CATALOGAÇÃO}

NASCIMENTO, G. T. do. Prevalência e Fatores de Risco da Tuberculose Bovina no

Distrito Federal, Brasil, 2015. Brasília: Faculdade de Agronomia e Medicina Veterinária, Universidade de Brasília, 2016, 66 p. Dissertação de Mestrado.

Documento formal autorizando reprodução desta dissertação de Mestrado para empréstimo ou comercialização, exclusivamente para fins acadêmicos, foi passado pelo autor à Universidade de Brasília e acha-se arquivado na Secretaria do Programa. O autor reserva para si os outros direitos autorais, de publicação. Nenhuma parte desta dissertação de mestrado pode ser reproduzida sem a autorização por escrito do autor. Citações são estimuladas, desde que citada a fonte.

FICHA CATOLOGRÁFICA

$\mathrm{Tp}$

Nascimento, Geraldo Teixeira do

Prevalência e Fatores de Risco da Tuberculose Bovina no Distrito Federal, Brasil, 2015 / Geraldo Teixeira do Nascimento

Orientador Vítor Salvador Picão Gonçalves. Brasília, 2016. 66 p.: il.

Dissertação (Mestrado - Mestrado em Saúde Animal Universidade de Brasília, 2016).

1. Mycobacterium bovis. 2. Prevalência aparente.

3. Regressão logística múltipla. 4. DF. I. Salvador

Picão Gonçalves, Vítor, orient. II. Título. 


\section{EPÍGRAFE}

"Há um tempo em que é preciso abandonar as roupas usadas que já têm a forma do nosso corpo, e esquecer os nossos caminhos, que nos levam sempre aos mesmos lugares. É o tempo da travessia: e, se não ousarmos fazê-la, teremos ficado para sempre à margem de nós mesmos."

Fernando Teixeira de Andrade 
DEDICATÓRIA

À Soraya, Fernanda, Ana Luísa e Geraldo Filho, fontes inesgotáveis de motivação e reconhecimento. 


\section{AGRADECIMENTOS}

Ao Prof. Dr. Vítor Salvador Picão Gonçalves, orientador, pelo exemplo de profissionalismo, devoção e comprometimento com as causas da defesa sanitária animal nas instituições acadêmicas e de defesa sanitária animal do país; figura propulsora e maior incentivador deste intento. Obrigado pela confiança e pelas lições desde os tempos do Instituto Mineiro de Agropecuária (IMA).

À colega e $\operatorname{Prof}^{\mathrm{a}} \operatorname{Dr}^{\mathrm{a}}$ Ana Lourdes Arrais de Alencar Mota, pela atenção, disponibilidade, paciência, ensinamentos, colaboração e todo empenho em busca da perfeição.

Aos colegas do Epiplan-FAV-UnB, Mariana, Geórgia, Marina, Cátia, Janaína, Flávio, Geraldo Moraes e Ana Lourdes pela acolhida e opiniões sempre pertinentes.

Aos professores da FAV-UnB, José Renato Borges, Fabiano Sant'Ana e Simone Perecmanis, pelo apoio e incentivo.

Aos professores do Núcleo de Medicina Tropical da Faculdade de Medicina da UnB, em especial à Prof. ${ }^{\mathrm{a}}$ Elisabete Carmem Duarte, pelos valiosos ensinamentos.

Aos membros da banca examinadora, Prof. Dr. Fernando Ferreira e Prof. Dr. Marcos Bryan Heinemann, pelas sugestões e críticas, oportunas e enriquecedoras.

À SEAGRI-DF - Secretaria de Estado da Agricultura, Abastecimento e Desenvolvimento Rural do Distrito Federal, por viabilizar a realização do Estudo Epidemiológico e pela flexibilização dos horários de trabalho, permitindo sua conciliação com o cumprimento das atividades acadêmicas.

Aos produtores rurais que participaram do estudo epidemiológico, pela disponibilização de suas propriedades e de seus animais para a coleta das informações e realização dos testes de tuberculinização.

Aos gestores e colegas do Serviço Veterinário Oficial da SEAGRI-DF, voluntariosos e determinados, exemplos de competência e conduta ética. Agradeço por cada gota de suor despendida na condução das atividades de campo e por cada minuto dedicado à organização da papelada do Estudo. À Mariana Gois e ao Daniel Buso pela especial colaboração na confecção dos mapas.

Ao Dr. Pedro Moacyr Pinto Coelho Mota, Coordenador do DBIO/LANAGRO/MG, pelo apoio e fornecimento de parte dos insumos utilizados na realização dos testes de tuberculinização. 
Aos colegas José Ricardo Lôbo e Gabriela Bicca da Silveira, cujo convívio durante minha passagem pelo PNCEBT no Ministério da Agricultura, Pecuária e Abastecimento conduziu-nos para muito além dos laços profissionais.

À Dona Fizinha, Mãe, pela existência, fé inabalável e pelas constantes orações.

Aos meus irmãos e familiares, incentivadores permanentes, ainda que à distância e até, em outra dimensão.

À minha esposa Soraya e aos meus filhos Fernanda, Ana Luísa e Geraldo Filho pelo apoio incondicional e pela compreensão à ausência que um trabalho como este nos submete.

A todos que, de maneira direta ou indireta, contribuíram para a realização deste trabalho.

Ao violão, pelo silêncio, peço perdão

Um tanto contido... guardado...

Em tempos de dupla ocupação. 


\section{SUMÁRIO}

\section{CAPÍTULO I}

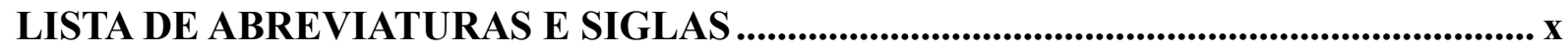

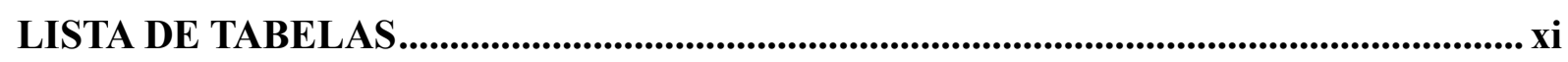

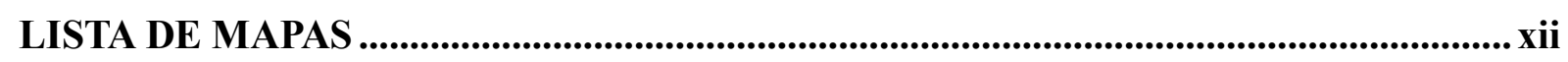

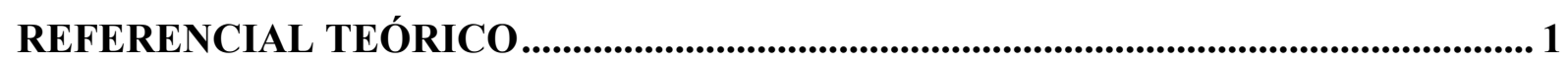

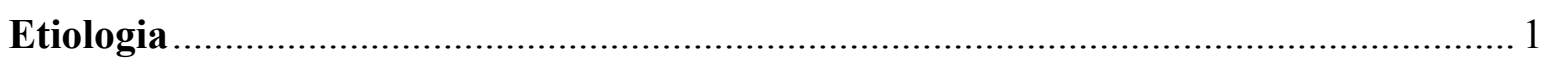

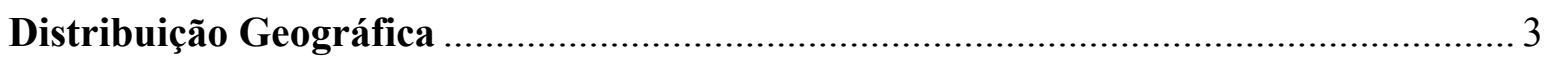

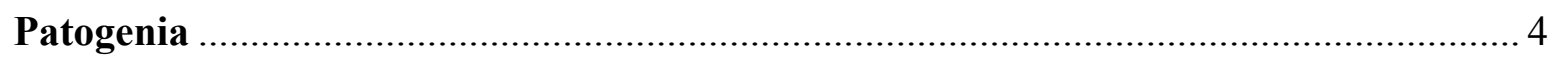

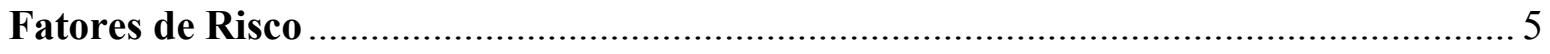

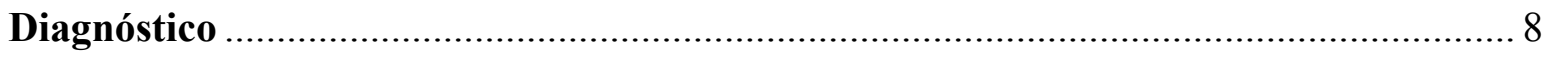

Importância Econômica e em Saúde Pública ........................................................... 13

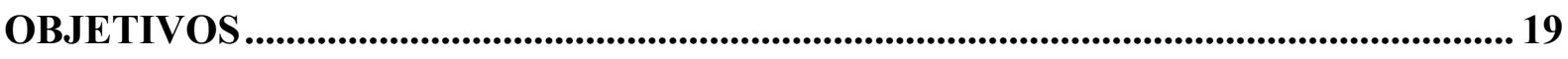

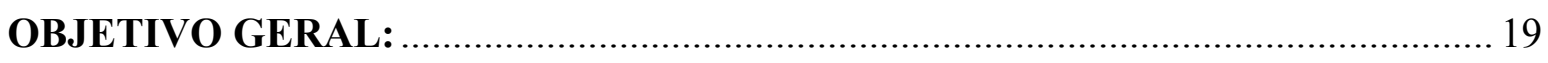

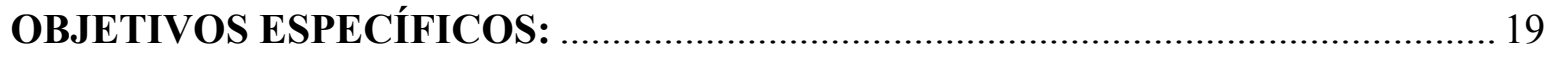

\section{CAPÍTULO II}

REFERÊNCIAS BIBLIOGRÁFICAS ...................................................................... 20

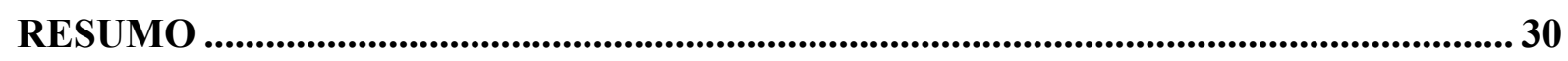

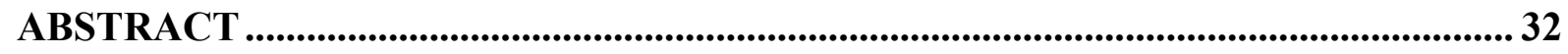

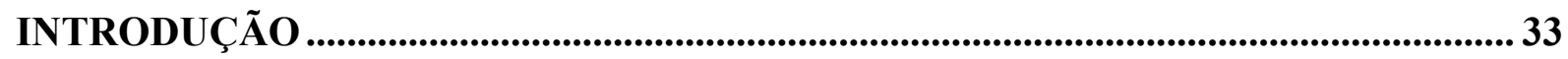

MATERIAL E MÉTODOS......................................................................................... 34

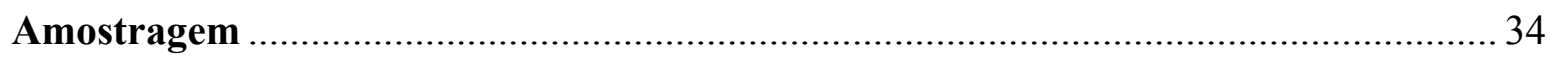

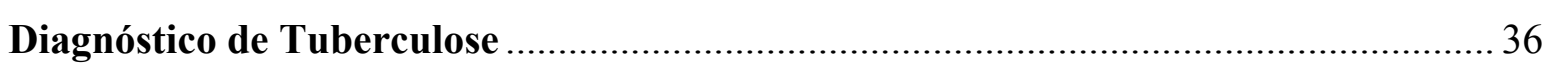

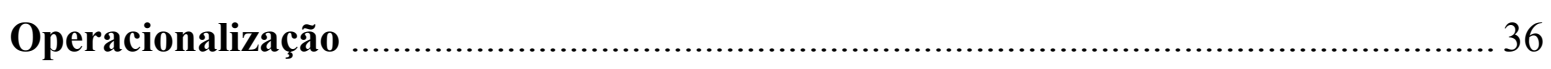

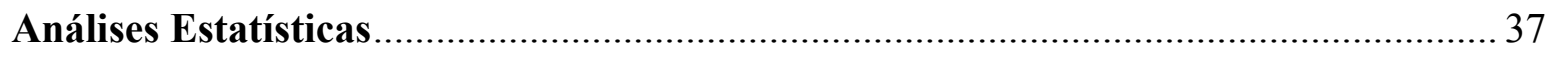

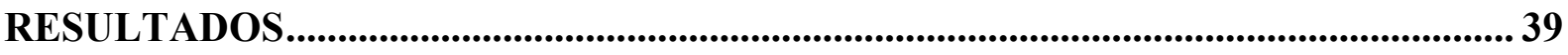

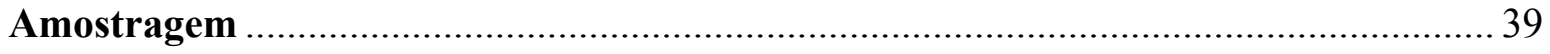

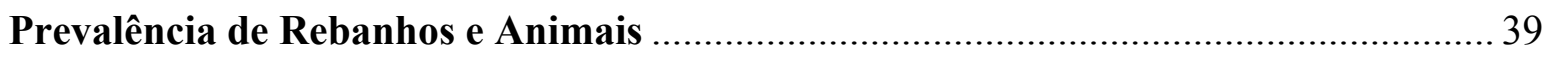

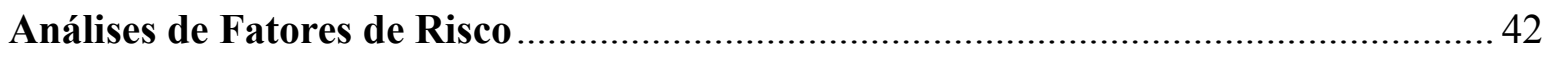

DISCUSSÃO E CONCLUSÕES.................................................................................45

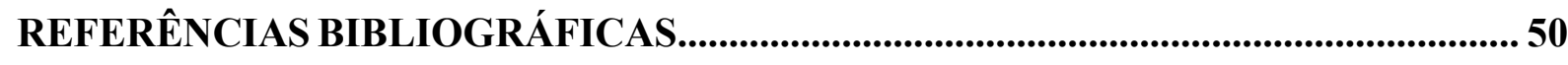




\section{LISTA DE ABREVIATURAS E SIGLAS}

\begin{tabular}{|c|c|}
\hline AIDS & Síndrome da Imunodeficiência Adquirida \\
\hline BAAR & Bacilo Álcool-Ácido Resistente \\
\hline BCG & Bacillus Calmette-Gérin \\
\hline BVD & Diarreia Viral Bovina \\
\hline CODEPLAN & Companhia de Planejamento do Distrito Federal \\
\hline DEFRA & Department for Environment, Food and Rural Affairs \\
\hline DF & Distrito Federal \\
\hline EMATER & Empresa de Assistência Técnica e Extensão Rural \\
\hline FAO & Food and Agriculture Organization of the United Nations \\
\hline FAV & Faculdade de Agronomia e Medicina Veterinária \\
\hline FMVZ & Faculdade de Medicina Veterinária e Zootecnia \\
\hline HIV & Vírus da imunodeficiência humana (Human Immunodeficiency Virus) \\
\hline IBGE & Instituto Brasileiro de Geografia e Estatística \\
\hline IFN- $\gamma$ & Interferon-gama \\
\hline $\operatorname{IgG}$ & Imunoglobulina $\mathrm{G}$ \\
\hline M. avium & Mycobacterium avium \\
\hline M. bovis & Mycobacterium bovis \\
\hline M. tuberculosis & Mycobacterium tuberculosis \\
\hline MAC & Complexo Micobaterium-intracellulare \\
\hline Mapa & Ministério da Agricultura, Pecuária e Abastecimento \\
\hline OIE & Organização Mundial de Saúde Animal \\
\hline PCR & Reação em cadeia da polimerase (polymerase chain reaction) \\
\hline PNCEBT & $\begin{array}{l}\text { Programa Nacional de Controle e Erradicação da Brucelose e da } \\
\text { Tuberculose Animal }\end{array}$ \\
\hline PPD & Derivado proteico purificado (purified protein derivative) \\
\hline SEAGRI & $\begin{array}{l}\text { Secretaria de Estado da Agricultura, Abastecimento e Desenvolvimento } \\
\text { Rural }\end{array}$ \\
\hline $\mathrm{SVS} / \mathrm{MS}$ & Secretaria de Vigilância Sanitária do Ministério da Saúde \\
\hline TB & Tuberculose Bovina \\
\hline TCC & Teste Cervical Comparativo \\
\hline Th & Linfócito T auxiliar (helper) \\
\hline UF & Unidade Federativa \\
\hline UnB & Universidade de Brasília \\
\hline USP & Universidade de São Paulo \\
\hline VPP & Valor Preditivo Positivo \\
\hline WHO & Organização Mundial de Saúde \\
\hline$\mu \mathrm{m}$ & Micrômetro \\
\hline NB & Nível de Biossegurança \\
\hline$\chi^{2}$ & Teste do Qui-Quadrado \\
\hline
\end{tabular}




\section{LISTA DE TABELAS}

Página

Tabela 1. Distribuição das propriedades amostradas por subpopulação e região 39 pecuária do Distrito Federal

Tabela 2. Dados censitários da população bovina do Distrito Federal, por tamanho 40 de rebanho

Tabela 3. Prevalência aparente de rebanhos para tuberculose bovina no Distrito Federal, por tamanho de rebanho

Tabela 4. Prevalência de tuberculose bovina em fêmeas com 24 meses ou mais no Distrito Federal, por tamanho de rebanho

Tabela 5. Estimativa do número de rebanhos infectados no Distrito Federal

Tabela 6. Análise univariada indicando variáveis com valor de $\mathrm{p} \leq 0,20$, testadas 43 para associação com rebanhos positivos

Tabela 7. Modelo de regressão logística no formato design-based (Hosmer, 44 Lemeshow \& Sturdivant (2013)

Tabela 8. Descrição das propriedades que resfriam o leite no Distrito Federal, 44 restrita àquelas que produzem leite (leite ou mistas)

Tabela 9. Tabela de classificação de risco das UFs para tuberculose bovina e 49 bubalina 


\section{LISTA DE MAPAS}

Página

Mapa 1.1. Distribuição e incidência mundial da tuberculose bovina no primeiro e 3 segundo semestre de 2015.

Mapa 1.2. Incidência mundial de tuberculose humana estimada em 2014.

Mapa 2.1. Demonstrativo da distribuição espacial dos rebanhos positivos no DF 


\section{CAPÍTULO I}

\section{REFERENCIAL TEÓRICO}

\section{Etiologia}

A tuberculose bovina é uma doença infectocontagiosa, com evolução predominantemente crônica e com potencial zoonótico. É causada pelo Mycobacterium bovis, bactéria que pertence ao gênero Mycobacterium, família Mycobacteriacea e ordem Actinomycetales. (THOEN E STEELE 1995). É um bastonete álcool-ácido resistente (BAAR), ou seja, quando corado pela fucsina a quente não se descora pela ação do álcool clorídrico (coloração de Ziehl-Neelsen), podendo ser visualizados à microscopia direta sob a forma de cocobacilos a bacilos, dependendo do tempo de cultivo. Tal característica deve-se aos ácidos micólicos, que são ácidos graxos de elevado peso molecular, presentes na parede celular diretamente responsáveis pela impermeabilização da superfície da micobatéria, conferindo-lhe características hidrofóbicas e resistência à maioria dos desinfetantes, dos antibacterianos e à dessecação (HOFFMAN et al., 2008), bem como, a álcool-ácido resistência, impedindo a eliminação dos corantes absorvidos (Murray et al., 2006). São aeróbicos, imóveis, não capsulados, não flagelados, não esporulados, gram-positivos, apresentando aspecto granular quando corados e medindo de 1 a $10 \mu \mathrm{m}$ de comprimento por 0,2 a 0,6 $\mu \mathrm{m}$ de largura (PALOMINO et al., 2007).

Embora as micobactérias não sejam bactérias formadoras de esporo, têm uma grande capacidade de permanecer viáveis em condições desfavoráveis. Em condições laboratoriais foi demonstrado que $50 \%$ dos M. bovis sobrevivem a $0^{\circ} \mathrm{C}$ por 36 dias, mas menos de $50 \%$ conseguem sobreviver por um dia a $16^{\circ} \mathrm{C}$. Com relação à umidade, $50 \%$ dos microrganismos sobreviveram por 43 dias com $100 \%$ de umidade, 8 dias a $57 \%$ e menos de um dia a $5 \%$. Cerca de $20 \%$ das micobactérias são inativadas quando expostas a luz ultravioleta por 20 minutos (GOODCHILD \& CLIFTON-HADLEY, 2001). M. bovis pode permanecer viável em estábulos, pasto e esterco por até 2 anos, por até 1 ano na água e por até 10 meses nos produtos de origem animal contaminados (RUSSEL et al., 1984). Em condições de anaerobiose no tanque de chorume, o M. bovis pode ficar viável por períodos de até 26 semanas (GOODCHILD \& CLIFTON-HADLEY, 2001).

É sensível aos desinfetantes fenólicos, formólicos, álcool e em especial ao hipoclorito de sódio ou cálcio a 5\%, que têm ação efetiva sobre o microrganismo, mas sua 
ação pode ser afetada pela concentração do produto, tempo de exposição, temperatura e presença de matéria orgânica. Já os compostos de amônio quaternários e clohexidine não destroem a bactéria (RUSSEL et al., 1984). O calor úmido a $60^{\circ} \mathrm{C}$ inativa o $M$. bovis rapidamente. A pasteurização, consistindo no tratamento do leite a $62,8-65,60 \mathrm{C}$ por $30 \mathrm{~min}$ ou $71,70 \mathrm{C}$ por $15 \mathrm{~s}$ inativa além das micobactérias, a maioria dos microrganismos nãoesporulados (RUSSEL et al., 1984).

Este agente infeccioso está classificado como patógeno de risco biológico de nível 3 para a saúde pública (THOEN et al., 2006), que inclui os patógenos que oferecem alto risco individual e moderado risco para a comunidade, requerendo medidas de biossegurança para sua manipulação de nível NB-3 (QUINN et al., 2011).

O Mycobacterium bovis integra o complexo Mycobacterium tuberculosis ao qual pertencem ainda o M. tuberculosis, que causa a tuberculose humana, M. bovis-Bacille Calmette-Guérin (BCG) - derivado de M. bovis que, por cultivos sucessivos em meio de batata glicerinada com bile bovina perdeu sua virulência conservando, porém, a propriedade de proteção imunológica contra M. tuberculosis e M. bovis; M. caprae, causador da doença em caprinos; M. africanum, detectado em casos de tuberculose humana no continente Africano; M. microti, que causa tuberculose em roedores; M. pinnipedii, causador da doença em leões marinhos e em humanos; e $M$. canettii, variante de $M$. tuberculosis encontrada na região da Somália e, mais recentemente, $M$. mungi, isolada numa população de mangustos (Mungos mungo) em Botswana (HADDAD et al., 2005; ALEXANDER et al., 2010).

O principal agente da tuberculose em humanos é o Mycobacterium tuberculosis, no entanto, este pode infectar também bovinos e interferir nas provas de tuberculinização. É menos patogênico para esta espécie, não causando doença progressiva e desaparecendo com a eliminação da fonte humana de infecção (OCEPECK et al., 2005) contudo, já foi isolado na Índia em leite não pasteurizado, demonstrando uma possibilidade de transmissão deste agente ao homem pelo bovino (SRIVASTAVA et al., 2008). A existência de estirpes de $M$. tuberculosis adaptadas aos bovinos e que permitam a transmissão do agente entre bovinos e destes para humanos não está completamente esclarecida (MICHEL et al., 2010).

A designação do Complexo M. avium-intracellulare (MAC), refere-se a um grupo de micobactérias muito semelhantes ao Mycobacterium avium, agente etiológico da tuberculose aviária e suína. Essas micobactérias não são patogênicas para os bovinos e bubalinos, mas provocam reações inespecíficas, interferindo nas provas de tuberculinização (DVORSKA et al., 2004; BARRY et al., 2011). 


\section{Distribuição Geográfica}

A tuberculose bovina encontra-se disseminada por todo o mundo e sua prevalência varia de acordo com a realidade de cada país (MICHEL et al., 2010, OIE 2016). Anualmente, são diagnosticados dez milhões de novos casos dessa enfermidade no mundo (JÚNIOR \& SOUZA, 2008; HUMBLET et al., 2009). Nos países desenvolvidos, de forma geral, onde os programas de controle e erradicação encontram-se em fase avançada, a exemplo dos Estados Unidos, Canadá, Reino Unido e outros países da Europa (CASTRO et al., 2009), as prevalências são mais baixas. Já nos países em desenvolvimento, onde as ações são normalmente tardias, sujeitas a uma série de dificuldades e, muitas vezes sem a necessária continuidade, a prevalência é geralmente maior (LÔBO, 2008; JÚNIOR \& SOUZA, 2008; HUMBLET et al., 2009). No entanto, observa-se nos últimos anos uma reemergência da doença em alguns países desenvolvidos, como Nova Zelândia, Estados Unidos (estado de Michigan), Reino Unido, Irlanda e Espanha associada a reservatórios selvagens (THOEN et al., 2009).

$\mathrm{Na}$ América Latina e no Caribe existem áreas onde a prevalência da tuberculose bovina ultrapassa $1 \%$ de animais positivos. Nestas regiões, a maior parte dos países aplica medidas, de forma parcial ou abrangente, para controlar a tuberculose bovina. Essas medidas são baseadas no teste e sacrifício de animais positivos, notificação de suspeitas e vigilância em matadouros (KANTOR \& RITACCO, 2006).

O Mapa 1 ilustra a distribuição da doença nos diferentes continentes e países no primeiro e segundo semestres de 2015 (OIE, 2016).

Mapa 1.1. Distribuição e incidência mundial da tuberculose bovina no primeiro e segundo semestre de 2015.

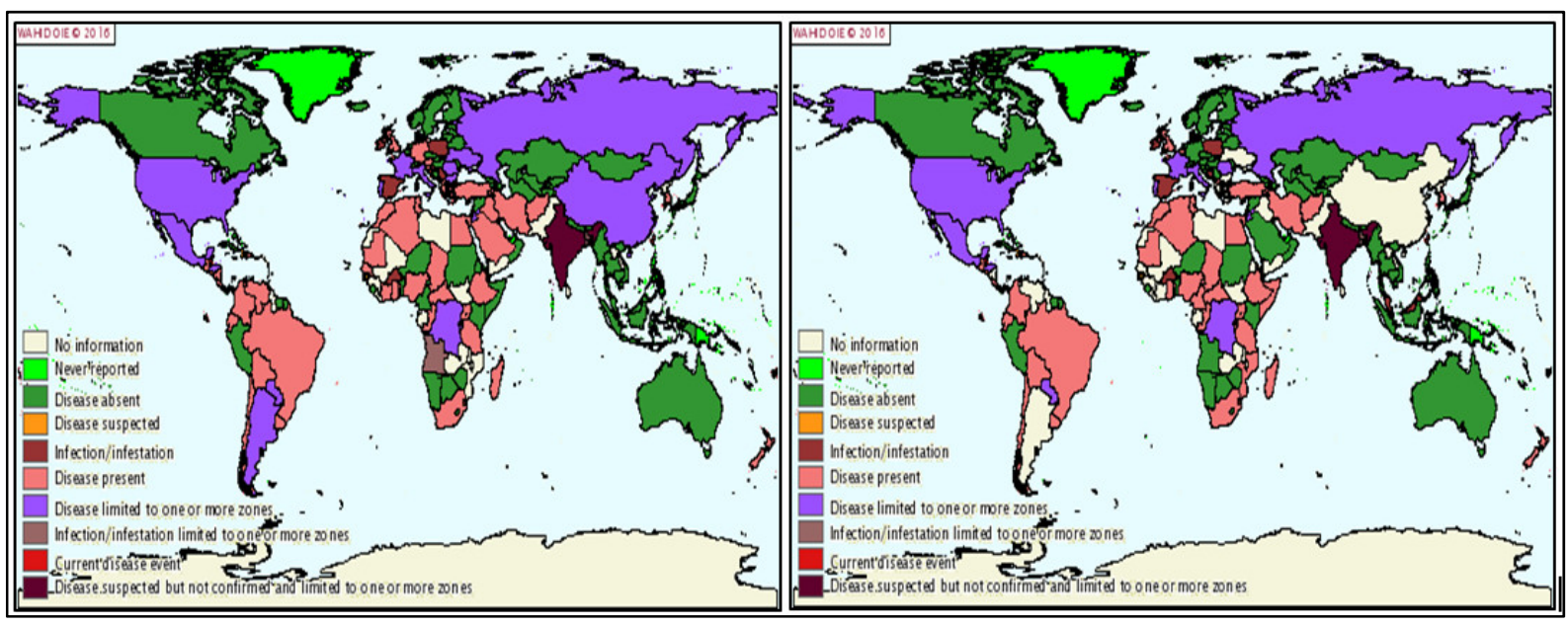

Fonte: OIE, 2016 
No Brasil, estudos epidemiológicos conduzidos em 13 Unidades Federativas (Distrito Federal, Espirito Santo, Bahia, São Paulo, Mato Grosso do Sul, Pernambuco, Mato Grosso, Rio Grande do Sul, Goiás, Santa Catarina, São Paulo, Rondônia e Paraná), realizados entre os anos de 1999 e 2015, demonstraram que a tuberculose bovina encontra-se distribuída de forma homogênea no país, apresentando baixas prevalências em rebanhos e animais.

\section{Patogenia}

Aproximadamente $90 \%$ das infecções por $M$. bovis ocorrem pela via respiratória, por meio da inalação de aerossóis contaminados com o microrganismo. A fonte primária dos aerossóis são as secreções respiratórias dos animais infectados e, para que a transmissão tenha sucesso, deve haver contato próximo entre os animais infectados e os suscetíveis (POLLOCK et al., 2006; HEINEMANN et al., 2008). Por ser o trato respiratório a principal porta de entrada do M. bovis nos bovinos, as lesões estão predominante distribuídas no trato respiratório e nos linfonodos associados a ele (CASSIDY, 2006; PALMER e WATERS, 2006).

Após a entrada do agente no animal e uma vez atingido o alvéolo, o $M$. bovis é capturado por macrófagos, sendo o seu destino determinado pela virulência do microrganismo, pela carga infectante e pela resistência do hospedeiro Os macrófagos são os sítios primários da multiplicação intracelular do M. bovis. Os macrófagos alveolares ativados são capazes de destruir pequenas quantidades de M. bovis, prevenindo o estabelecimento da doença. Entretanto, se os microrganismos não forem destruídos, poderão se multiplicar intracelularmente nos macrófagos não ativados que entram nos alvéolos através da corrente sanguínea (DANNENBERG 2001; POLLOCK et al. 2006).

Os linfócitos T (célula-T) são os maiores indutores de proteção adquirida (BUDDLE et al. 2002a). As células-T auxiliares (Th-1) são de particular importância na defesa contra patógenos intracelulares (POLLOCK, WELSH \& McNAIR 2005). Quando um animal é infectado pelas micobactérias os antígenos micobacterianos induzem a memória celular mediada pela Th-1, o que constitui a base da resposta ao diagnóstico por meio do teste de tuberculinização (TIZARD 2009). A imunidade celular é caracterizada pela expressiva produção de citocinas, entre elas o interferon-gama (IFN- $\gamma$ ), essencial para a estimulação da atividade microbicida dos macrófagos. Em bovinos infectados pelo M. bovis, o CD4 parece ser o maior produtor de IFN- $\gamma$; células $\gamma \delta$ também são potenciais fontes desta citocina, porém em menor escala (POLLOCK, WELSH \& McNAIR 2005). 
As lesões iniciais causadas por M. bovis podem regredir, permanecerem estáveis ou se desenvolverem causando infecção generalizada no organismo. Esse desenvolvimento pode se dar em duas fases: o complexo primário e o pós-primário. O complexo primário é constituído pela lesão inicial, na qual houve a primo infecção com comprometimento do linfonodo regional. A generalização da tuberculose ocorre na fase pós-primária e pode assumir a forma miliar aguda ou a forma protraída. $\mathrm{Na}$ forma miliar aguda, ocorre a distribuição sistêmica de grande carga bacilar através da circulação, causando discretas lesões espalhadas por vários órgãos. Já na forma protraída, há disseminação do agente, por via circulatória ou linfática, por reinfecção contínua em outros tecidos, podendo acometer praticamente todo o sistema, pela recrudescência da lesão ou por reinfecção exógena. $\mathrm{O}$ desenvolvimento da doença pode ocorrer precocemente ou numa fase tardia, em decorrência de uma queda na imunidade animal (RADOSTITS et al., 2002; BRASIL, 2006).

O complexo primário pode se apresentar como um nódulo cujo tamanho varia entre uma ervilha e uma noz, de aspecto caseoso, de cor vítreo ou amarelado, podendo estar localizado no parênquima do pulmão ou na parede intestinal, dependendo da rota primária de infecção, oral para os bezerros e a respiratória para os animais adultos (RADOSTITS et al., 2002; SMITH, 2006).

Lesões no trato respiratório e em seus linfonodos podem ser observadas a partir de 14 dias pós-infecção. Microscopicamente, são observadas a partir de 7 a 11 dias pós-infecção (DANNENBERG, 2001; POLLOCK et al., 2006). A aparência da lesão pulmonar varia com progressão da infecção. No início, há formação de pequenos nódulos branco-amarelados únicos ou múltiplos não encapsulados. Esses nódulos possuem o centro necrótico e caseoso e os mais antigos podem ranger ao corte devido à calcificação. Linfonodos estão aumentados de volume e com lesões nodulares únicas ou múltiplas branco-amareladas (PAIXÃO et al., 2008).

$\mathrm{Na}$ inspeção realizada em frigoríficos, diversas doenças, como actinobacilose, piogranuloma estafilocócico, mucormicose, coccidioidomicose, pentastomíase, hidatidose policística e alguns tumores, apresentam lesões macroscópicas similares à tuberculose. Para diferenciar a tuberculose dessas lesões, são necessários exames histopatológicos e microbiológicos (RIET-CORREA \& GARCIA, 2001).

\section{Fatores de Risco}

Os fatores de risco associados à presença da tuberculose bovina podem estar 
relacionados ao animal, ao rebanho, a região e ao país. Entre os principais fatores associados ao animal, pode ser citada a idade, raça, estado nutricional, resistência genética e estado imune. Os fatores relacionados ao rebanho são o tamanho, densidade populacional, tipo de exploração, sistema de produção, contato com animais silvestres, ingresso de animais, falta de realização de exames diagnósticos, dentre outras práticas zootécnicas e sanitárias. Com relação à região e ao país, deve ser observado o histórico de prevalência da doença nos bovinos da propriedade e da região, o comércio e a movimentação de animais (HUMBLET et al., 2009).

A idade dos animais pode influenciar a susceptibilidade à doença. Observou-se associação entre a doença e a evolução da idade dos animais, provavelmente devido ao aumento da exposição dos suscetíveis a animais infectados (KAZWALA et al. 2001) ou a infecções adquiridas enquanto jovens e que permaneceram em estado latente (PALMER \& WATERS, 2006).

O gênero não está consolidado como fator predisponente da doença, contudo, uma maior incidência em fêmeas poderá estar relacionada a particularidades de manejo, bem como ao tempo de vida útil mais prolongado associado aos processos de reprodução e de aleitamento (HUMBLET et al., 2009).

Outro fator de risco de tuberculose em bovinos, relacionado ao animal, é a imunossupressão, que predispõe os animais a várias infecções, entre elas, ao Mycobacterium bovis (MENZIES \& NEILL, 2000). de La Rua-Domenech et al. (2006) correlacionaram a imunossupressão pré e pós o parto e infecções concomitantes com vírus da diarreia viral bovina (BVD), como causas de resultados falso-negativos aos testes alérgicos e não necessariamente como fator de risco.

Em nível de rebanho, a infecção por $M$. bovis é mais provável quanto maior a proximidade entre os animais, por isso, a introdução e a manutenção da tuberculose bovina em um rebanho é fortemente influenciada pelas características da unidade de criação (GOODCHILD \& CLIFTON-HADLEY, 2001).

Apesar de vários pesquisadores considerarem o tamanho do rebanho um importante fator de risco, na realidade a sua associação com a presença da tuberculose se dá pela densidade populacional (GRIFFIN et al., 1996; MUNROE et al., 1999; PORPHYRE et al., 2008). Quando se menciona tamanho de rebanho, está se referindo à probabilidade de contato efetivo entre o animal infectado e um susceptível (COOK et al., 1996; CLEAVELAND et al., 2007). A principal via de transmissão da tuberculose bovina nestes casos é a aerógena, pois o 
contato entre animais facilita a transmissão via aerossóis (MENZIES e NEILL, 2000).

Com relação ao tipo de exploração como fator de risco, grande parte das pesquisas mostra que os rebanhos de produção leiteira apresentam prevalências mais elevadas para tuberculose comparadas aos rebanhos de corte (COSIVI et al., 1998; HUMBLET et al., 2009; BELCHIOR, 2016, SILVA et al., 2016; BAHIENSE et al., 2016; VENDRAME et al., 2016; NESPOLI et al., 2016; VELOSO et al., 2016; ROCHA et al., 2016). De acordo com Salazar (2005), o risco de infecção em bovinos de corte é mínimo quando mantidos em baixa densidade populacional e em pastagens, mas quando mantidos em confinamento, o risco de transmissão é semelhante ao dos rebanhos leiteiros. Outro fator de risco considerado para a tuberculose está relacionado a reservatórios na fauna silvestre e os possíveis contatos que podem manter com as explorações pecuárias, pois favorecem um ciclo de transmissão do agente entre bovinos-espécies silvestres-bovinos (MICHEL et al., 2010).

O M. bovis possui o maior número de hospedeiros entre as micobactérias e patogenicidade variável entre as espécies hospedeiras (DENNY e WILESMITH, 1999). Além das espécies domésticas (bovinos, gatos, cachorros, suínos, búfalos, coelhos, ovinos e equinos), várias espécies de animais selvagens são passíveis de infecção pelo agente (macacos, elefantes, girafas, leões, tigres, leopardos, javalis, lebres, texugos, ratos, roedores, focas, camelos, raposas, veados, lhamas e furões). (PHILLIPS et al., 2003). Qualquer um desses animais susceptíveis pode agir como potencial reservatório da doença e servir como fonte de infecção para os bovinos e para o homem. Nesses casos a contaminação pode ocorrer não só pelo contato direto, mas pelo contato com fezes e urina de animais contaminados (PHILLIPS et al., 2003). A importância de cada reservatório depende do grau de contato com os bovinos e da possibilidade de transmitir o agente para os mesmos (PHILLIPS et al., 2003).

Em países desenvolvidos, onde a tuberculose bovina encontra-se em fase final de erradicação ou já erradicada, espécies silvestres assumem importância como reservatório do M. bovis para bovinos. Algumas espécies de animais selvagens já foram determinadas como epidemiologicamente relevantes: os javalis (Sus scrofa) e búfalos (Bubalus bubalis) ferais na Austrália, o veado de cauda branca (Odocoileus virginianus) nos Estados Unidos da América, o marsupial Trichosurus vulpecula e o furão (Mustela furo) na Nova Zelândia, o texugo (Meles meles) na Irlanda e Inglaterra (CORNER, 2006; KANEENE e PFEIFFER, 2006; HEINEMANN et al. 2008), o bisonte americano (Bison bison) e algumas espécies da família Cervidae (Cervus elaphus manitobensis e Odocoileus virginianus) no Canadá (NISHI et al., 2006; WOBESER, 2009), o javali (Sus scrofa) e o veado (Cervus elaphus) na Espanha (de 
MENDOZA et al., 2006; NARANJO et al., 2008).

Os texugos são numerosos no Reino Unido e são conhecidos por provocarem danos às culturas de milho e por invadirem os galpões de ração e silagem destinadas ao gado, atraídos pelos alimentos destinados aos bovinos. Quando infectados pelo M. bovis, eliminam o agente pela urina, fezes ou expectoração, contaminando os alimentos e o ambiente, o que constitui uma provável via de transmissão aos rebanhos (REILLY \& COURTENAY, 2007). A despeito da reprovação de parte da população, nos últimos anos a Inglaterra tem patrocinado ações de extermínio destes mustelídeos em algumas regiões a fim de manter a tuberculose bovina em níveis aceitáveis (DEFRA 2016).

No Brasil, não há evidências de importância epidemiológica de nenhuma espécie feral ou silvestre na manutenção do Mycobacterium bovis em rebanhos bovinos. No entanto, as autoridades sanitárias brasileiras precisam estar atentas para evitar que, futuramente, animais silvestres façam parte da cadeia epidemiológica da tuberculose em bovinos (ABRAHÃO, 1999; HEINEMANN et al. 2008).

Skuce, Allen \& McDowell (2012), em revisão da literatura sobre estudos de fatores de risco realizados no Reino Unido e na Irlanda apontam a movimentação animal, a ocorrência da doença em áreas contíguas à propriedade e o tamanho do rebanho como os fatores de risco mais consistentes associados à transmissão da tuberculose bovina entre os rebanhos. Outros fatores identificados foram: histórico de incidência da doença, tamanho e tipo do rebanho; tipo de instalação; aquisição de animais a partir de rebanhos com histórico de tuberculose; fornecimento de alimento no interior de instalações e densidade ou atividade de espécies silvestres, como os texugos.

No Brasil, estudos de prevalência e fatores de risco conduzidos em Minas Gerais (BELCHIOR 2016), Paraná (SILVA et al. 2016), Bahia (BAHIENSE et al. 2016), Mato Grosso (NÉSPOLI et al. 2016), Rondônia (VENDRAME et al. 2016), Goiás (ROCHA et al. 2016) e Santa Catarina (VELOSO et al. 2016) identificaram como principal fator de risco a exploração leiteira, em geral associada a rebanhos maiores e com maior grau de tecnificação. Segundo Belchior (2016), a probabilidade de infecção aumenta nas propriedades de produção mais intensiva e tecnificada, o que pode estar relacionado a sistemas de criação animal em confinamento parcial ou total. Outros fatores de risco associados à ocorrência de tuberculose bovina nestes estudos incluem o tamanho do rebanho, a aquisição de animais e o compartilhamento de pastagens. 


\section{Diagnóstico}

Os métodos de diagnóstico utilizados para a detecção de animais infectados por $M$. bovis podem ser divididos em métodos diretos e métodos indiretos. Os primeiros são os que determinam a presença no animal do agente etiológico, seus componentes ou seus produtos derivados. A bacteriologia e a histopatologia correspondem a esta categoria. Os métodos indiretos determinam a resposta do animal ao agente etiológico. Essa resposta pode ser humoral (produção de anticorpos circulantes) ou celular (mediada por linfócitos e macrófagos), tal como a reação tuberculínica e a liberação de interferon-gama por linfócitos sensibilizados em presença da tuberculina (CORNER, 1994; CAGIOLA et al., 2004).

A reação tuberculínica, a bacteriologia e a histopatologia são os métodos mais utilizados na rotina do diagnóstico da tuberculose bovina. Também é utilizado com bastante frequência, a campo, o diagnóstico clínico associado à tuberculinização, que possibilita, algumas vezes, identificar animais com tuberculose em estágio avançado que geralmente apresentam um decréscimo da sensibilização alérgica, às vezes chegando à anergia. Pode-se dizer que existem métodos de diagnóstico adequados para o desenvolvimento de programas de controle e erradicação da tuberculose bovina, entretanto, não existe um método que tenha uma eficácia absoluta (BRASIL, 2006).

O método diagnóstico mais tradicionalmente empregado é a tuberculinização que utiliza antígenos (tuberculinas) inoculados por via intradérmica. As tuberculinas utilizadas são derivados proteicos purificados (PPD - Purified Protein Derivative), obtidos a partir do crescimento e tratamento térmico de culturas de micobactérias. (POLLOCK et al., 2005; de La RUA-DOMENECH et al., 2006) .

A tuberculina inoculada em um animal infectado é fagocidada pelas células de Langerhans, que a apresentam para células-T de memória. Células Th-1 produzem IFN- $\gamma$ ao reconhecerem o antígeno, ativando os macrófagos. Ocorre, então, uma reação de hipersensibilidade retardada ou tardia, caracterizada pela formação de edema e eritema no local da inoculação, que atinge o seu pico por volta das 48-72 horas pós-inoculação (POLLOCK et al., 2005; TIZARD 2009; de La RUA-DOMENECH et al., 2006; VELOSO, 2014).

Estes testes utilizando PPD apresentam problemas de especificidade, já que seus epítopos são compartilhados por várias micobactérias. A comparação entre a resposta induzida pela inoculação intradérmica de PPD bovino, extraído do $M$. bovis, com a resposta induzida pela inoculação do PPD aviário, obtido do $M$. avium, permite o aumento da 
especificidade tanto nos testes in vivo (tuberculinização intradérmica) quanto nos in vitro (teste do Interferon-gama) (PALMERS \& WATERS, 2006 apud VELOSO, 2014).

Resultados falso-negativos podem ocorrer à tuberculinização intradérmica, devido a uma deficiência do sistema imunitário - anergia, decorrente de vários fatores. $\mathrm{O}$ primeiro fator é a dessensibilização, que consiste na injeção de antígenos específicos em um indivíduo previamente imunizado. A dessensibilização parcial ocorre após uma inoculação intradérmica de tuberculina que é ampliada se altas concentrações do antígeno ou o número de inoculações for aumentado. Esta dessensibilização é de curta duração, entre 42 a 60 dias, em função da não reatividade dos clones de linfócitos $\mathrm{T}$ que reconhecem especificamente o antígeno. $\mathrm{O}$ segundo caso é uma deficiência orgânica do próprio sistema imunitário do indivíduo. Animais com deficiências nutricionais não conseguem desenvolver uma boa resposta imune e consequentemente não reagem ao teste alérgico. O terceiro caso ocorre em animais com tuberculose generalizada ou estágios finais da doença. Nestes casos, há um excesso de antígeno no organismo que induz a ativação mecanismos de proteção para se evitar que haja danos teciduais em decorrência da hiper estimulação do sistema imune. Este mecanismo de proteção do organismo leva ao aparecimento de células regulatórias ou supressoras que vão diminuir a resposta imune ao agente. Há também uma anergia no peri-parto, pois o mecanismo do parto é desencadeado por aumento de corticóides, com consequente diminuição da resposta imune celular. Desta forma, deve-se evitar a tuberculinização num período em torno de 15 a 30 dias antes do parto (MONAGHAM et al., 1994; DOHERTY et al., 1996; ABBAS et al., 2002; BRASIL, 2006). Animais com a doença clínica de Johne (paratuberculose), causada pelo Mycobacterium avium var. paratuberculosis, parecem desenvolver algum "fator bloqueador" que impede que as células-T reajam com o antígeno, provocando a ausência de reação ou anergia (TIZARD, 2009; VELOSO, 2014).

$\mathrm{O}$ teste do Interferon-gama é uma prova in vitro que mede a resposta de imunidade celular específica à infecção por M. bovis. Apresenta-se como alternativa ao teste de tuberculinização intradérmica, sendo desenvolvido para dar maior agilidade, sensibilidade e especificidade ao diagnóstico da tuberculose bovina. É também uma prova oficial de diagnóstico na União Européia, sendo normalmente utilizada como teste complementar à tuberculinização (OIE, 2012). Esta prova está fundamentada na dosagem in vitro da citocina IFN- $\gamma$ produzida em amostras de sangue total de animais infectados, após estimulação com tuberculina bovina. O teste é realizado em duas fases, inicialmente a amostra de sangue do animal suspeito é incubada com tuberculina bovina durante 16 a 24 horas, seguida da 
detecção e dosagem do IFN- $\gamma$ produzido, através de um teste ELISA (SCHILLER et al., 2010). Para evitar ocorrência de resultados falso-positivos, em razão das reações cruzadas com micobactérias inespecíficas, a prova comparada pode ser realizada utilizando-se concomitantemente a PPD Bovina e a PPD aviária (WOOD \& ROTHEL, 1994). Na Austrália, o teste indicou 93,6\% e especificidade de 96,3\% em condições de campo, o que o levou a ser o primeiro teste para o diagnóstico de tuberculose bovina a ser aprovado naquele país após a introdução da tuberculinização em 1890 (MYLREA, 1990).

A sensibilidade diagnóstica deste teste é considerada superior ao da tuberculinização intradérmica cervical comparada, porém a sua especificidade é menor, tornando-o inapropriado como teste único em zonas de baixa prevalência da doença (GORMLEY et al. 2006; SCHILLER et al. 2010,). No entanto, estudos incluindo a utilização de dois antígenos específicos do Complexo Mycobacterium tuberculosis, o ESAT-6 e o FP-10 em substituição ao PPD têm demonstrado aumentos na especificidade da prova (AAGAARD et al., 2010). Outras desvantagens estão relacionadas ao inconveniente do sangue heparinizado necessitar ser processado em, no máximo, 12 h após a colheita (WOOD e ROTHEL, 1994), o que restringiria a sua utilização àquelas regiões ou propriedades próximas de um laboratório que o realize (SAKAMOTO et al.), bem como, a aparente diminuição de sensibilidade em presença da paratuberculose (ÁLVAREZ et al., 2009).

Como teste in vitro, o teste do Interferon-gama propicia as vantagens de ser um procedimento não invasivo; não interfere com o estado imunitário do animal, não necessitando, portanto, de período refratário para repetição. Além disso, exibe rapidez de resposta, interpretação mais objetiva dos resultados (independente do operador) e facilita o manejo dos animais, ao exigir mobilização do rebanho e da mão de obra veterinária uma única vez para a colheita de sangue (de La RUA-DOMENECH et al., 2006).

Vários métodos para o diagnóstico específico da tuberculose bovina baseados nas alterações dos componentes séricos dos animais infectados pelo M. bovis foram propostos nos últimos anos, mas tiveram seu uso restrito pela baixa sensibilidade ou especificidade. Dentre os métodos que foram mais amplamente estudados, no Brasil e em outros países, estão os ensaios imunoenzimáticos. Estes testes são baseados na resposta imune humoral ao M. bovis, que, em geral, é baixa no início da infecção, mas elevada nos quadros mais avançados, sendo capazes de detectar animais com lesões mais extensas e os animais anérgicos, mas não animais com infecção inaparente, resultando em baixa sensibilidade (PLACKETT et al., 1989, HARBOE et al., 1990, RITACCO et al., 1991, FIFIS et al., 1994; de KANTOR \& 
RITACCO 1994; PALMERS \& WATERS 2006). Todavia, se utilizada em conjunto com outros testes, a sorologia pode desempenhar um papel importante na detecção de animais cuja resposta celular esteja inadequada, subsidiando a identificação e remoção, sobretudo de quadros mais severos e anérgicos. (POLLOCK et al,. 2005; VELOSO, 2014).

O diagnóstico post mortem da tuberculose bovina, durante a realização de necropsias ou inspeção sanitária de carcaças em matadouros-frigoríficos, apresenta consideráveis limitações devido à sua baixa especificidade, uma vez que, muitas lesões granulomatosas apresentam características morfológicas semelhantes às descritas para a tuberculose (OLIVEIRA et al., 1986; SALAZAR, 2005; LOPES FILHO, 2010). Contudo, a inspeção sanitária tem um papel importante na detecção de rebanhos infectados e, consequentemente, contribui ativamente para o sucesso dos programas de controle e erradicação da tuberculose bovina principalmente de regiões em que a doença apresenta uma prevalência muito baixa (CORNER et al., 1990; MILIAN-SUAZO et al., 2000). Isto porque o principal método de diagnóstico utilizado na triagem de animais infectados, o teste de tuberculinização intradérmica, não apresenta um valor preditivo adequado em situações de baixa prevalência necessitando de métodos de diagnóstico suporte no monitoramento de rebanhos (MILIANSUAZO et al., 2000; PAIXÃO et al. 2008). Desta forma, o serviço de inspeção sanitária de produtos de origem animal em abatedouros é uma ferramenta importante para a vigilância epidemiológica da tuberculose (PAIXÃO et al. 2008).

Nos Estado Unidos e Austrália, a vigilância nos matadouros é o principal meio para detecção de novos casos de TB (USA, 1994). Esta tem sido uma estratégia bem sucedida, mas alguns aspectos devem ser realçados (de KANTOR et al. 1987; CORNER 1990; USA 1994; CORNER 1994; VELOSO, 2014): (a) quando a prevalência é baixa, o VPP (Valor Preditivo Positivo) da inspeção visual é igualmente baixo (muitas lesões não são tuberculosas) e, por isso, as lesões precisam ser confirmadas por exame laboratorial; (b) a sensibilidade da inspeção de rotina é baixa - varia entre $33 \%$ e $67 \%$ - o que tem sido confirmado por inspeções mais criteriosas na localização de lesões. Muitos animais apresentam uma única lesão que na maioria das vezes é pouco detectada na inspeção de rotina.

Para o diagnóstico definitivo da tuberculose é necessário o cultivo e identificação do M. bovis. As técnicas bacteriológicas empregadas apresentam baixa sensibilidade, devido aos métodos empregados de descontaminação do material, que além de destruir os contaminantes, ao mesmo tempo eliminam alguns bacilos, dificultando o seu isolamento. Além disto, para o cultivo do M. bovis é necessário que as lesões apresentem uma 
concentração de bactérias igual ou superior a 10.000 unidades formadoras de colônia por mililitro (UFC/ml) e uma demanda de mais de 12 semanas para a obtenção dos resultados (CORNER, 1994; WARDS et al., 1995; ZANINI et al., 2001). Em função de sua baixa sensibilidade, a bacteriologia como método de diagnóstico geralmente é empregado em situações que demandam a conclusão definitiva do diagnóstico por meio do cultivo e identificação do M. bovis.

O M. bovis pode ser pesquisado pela visualização microscópica direta de amostras frescas coradas pelo método de Ziehl-Neelsen para pesquisa de BAAR (Bacilo Álcool-Ácido Resistente) (QUINN et al., 2004). A baciloscopia direta, entretanto tem baixo valor no diagnóstico da tuberculose bovina, ao contrário da tuberculose humana, uma vez que na maioria das lesões macroscópicas não são observados BAAR ao exame microscópico direto por não atingirem as concentrações mínimas para serem visualizados, cerca de 10.000 bacilos por mililitro (WARDS et al., 1995), além de que, esta técnica não permite a diferenciação dos membros da família Mycobacteriaceae de outros microrganismos tais como Corynebacterium $s p$, Nocardia sp e Rhodococcus sp, que têm as mesmas características tintoriais (QUINN et al., 2004).

Nos últimos anos, o desenvolvimento e o emprego de novos métodos no diagnóstico da tuberculose bovina utilizando-se de técnicas moleculares, trouxeram diversos avanços para o diagnóstico desta doença. Todavia, essas técnicas têm sido utilizadas de forma complementar em estudos da epidemiologia da tuberculose bovina, dadas as limitações associados aos altos custos, complexidade de realização das provas e interpretação de resultados, padronização das técnicas e, resultados nem sempre confiáveis com falso-positivos ou falso-negativos, sobretudo em amostras com baixa quantidade de bacilos. (OIE, 2012). As técnicas moleculares mais importantes são as baseadas na amplificação de ácidos nucleicos (PCR) associado com a rápida confirmação da doença e a genotipagem, que podem fornecer informações relevantes para o ciclo epidemiológico desta enfermidade (COLLINS, 2011).

\section{Importância Econômica e em Saúde Pública}

A tuberculose bovina é reconhecida como um grande problema de saúde animal em todo o mundo, afetando negativamente a produção e o comércio nacional e internacional de animais, além de ser uma ameaça à saúde humana (BOLADO-MARTINÉZ et al., 2014). Essa enfermidade ocasiona grandes perdas econômicas devido à morte de animais, queda na produção de leite e carne, diminuição progressiva da capacidade reprodutiva, descarte precoce 
e eliminação de animais de alto valor zootécnico, condenação de carcaças no abate, restrições às exportações e perda de prestígio e credibilidade da unidade de criação (GONÇALVES, 1998; ALVES et al., 2008; OLIVEIRA et al., 2008).

Estima-se que os animais infectados percam de 10 a $25 \%$ de sua eficiência produtiva (BERNUÉS et al.,1997; Mota 2008). Segundo de Kantor e Ritacco (1994) e O'Reilly e Daborn (1995), as perdas são mais evidenciadas em rebanhos leiteiros, decorrentes da diminuição da produção de leite e da eliminação precoce de matrizes. Estudos na Turquia estimaram que para o setor leiteiro $65 \%$ dos custos eram devidos a diminuição na produção de leite, $28 \%$ à redução da vida produtiva e $7 \%$ à redução da natalidade, o que produz um impacto sócio-econômico no agronegócio e na saúde pública do país de aproximadamente 15 a 59 milhões de dólares por ano (BARWINECK e TAYLOR, 1996; COSIVI et al., 1998). Na Argentina, a estimativa de perda anual em relação à tuberculose bovina é de aproximadamente 63 milhões de dólares (COSIVI et al., 1998).

$\mathrm{Na}$ Inglaterra, a tuberculose bovina custa aos contribuintes mais de 100 milhões de libras por ano. Em 2015, mais de 28 mil bovinos foram abatidos para controlar a doença naquele país (DEFRA, Health Protection Agency 2016).

Em estudo realizado por Baptista et al. (2004), a prevalência da tuberculose em bovinos abatidos em Minas Gerais, de 1993 a 1997, em frigoríficos sujeitos a inspeção federal foi de $0,7 \%$. A tuberculose respondeu por $1,86 \%$ dos aproveitamentos condicionais das carcaças, mas ocupou primeiro lugar na condenação destas para graxaria, sendo a principal causa de prejuízo, correspondendo a $28,23 \%$ das condenações.

Considerando-se a sáude humana, a epidemiologia da tuberculose bovina foi historicamente de grande interesse, em função de sua importância como zoonose, com graves consequências para a saúde pública (THOEN et al., 2006). A tuberculose humana é uma das doenças infecciosas mais disseminadas no mundo, com registro de nove milhões de novos casos e 1,5 milhão de mortes por ano (WHO 2014). O Mapa 2 mostra a incidência mundial da tuberculose em 2014. Entre adultos é a infecção que mais provoca mortes em função de um único agente infeccioso (ACHA e SZYFRES, 2003). Seu agente causador mais comum é o Mycobacterium tuberculosis, mas uma parte dos casos em humanos é atribuída ao M. bovis. 
Mapa 1.2. Incidência mundial de tuberculose humana estimada em 2014.

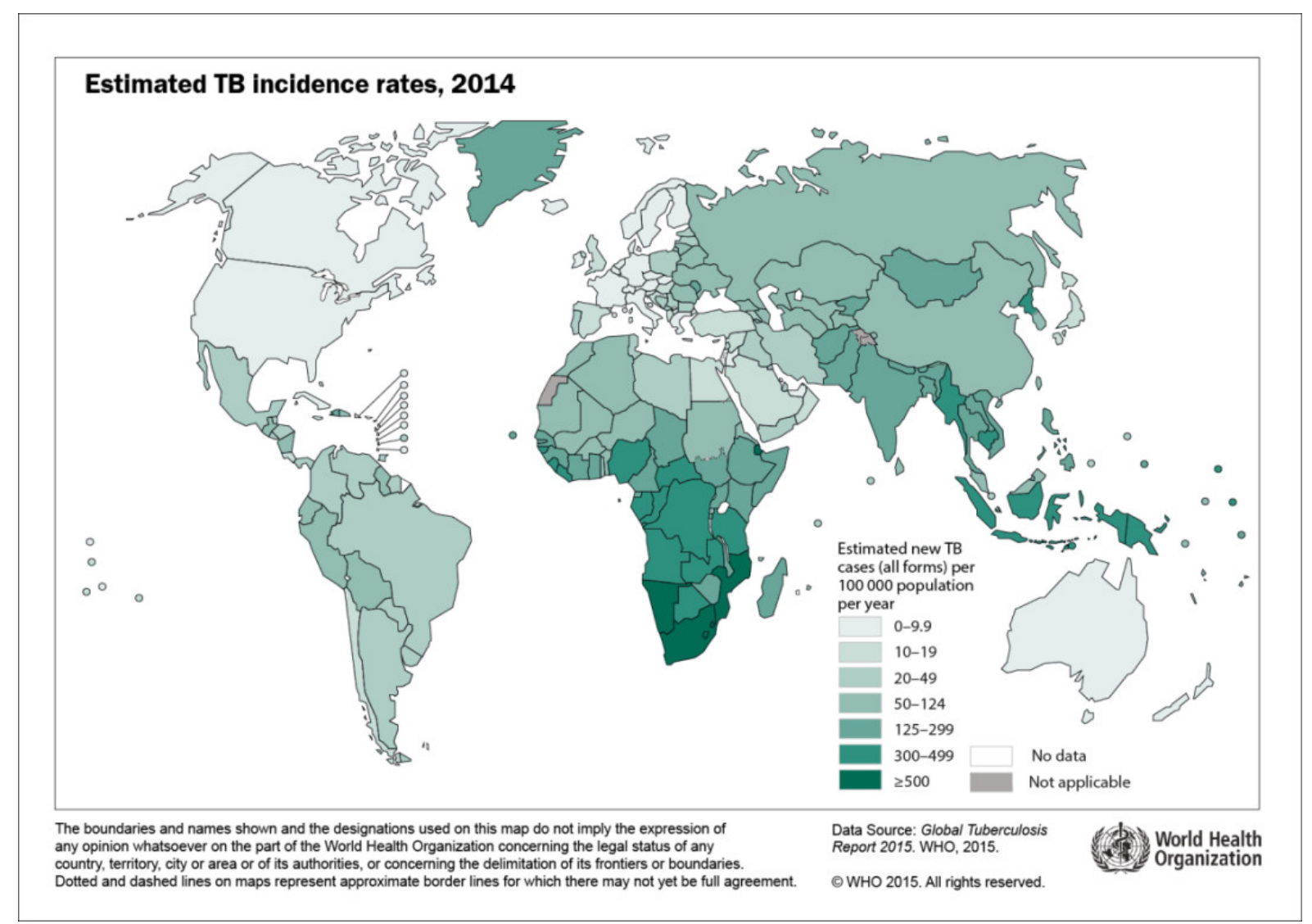

Fonte: Organização Mundial de Saúde (WHO, 2016).

A tuberculose em humanos causada por M. bovis ocorre na maioria das nações em desenvolvimento, onde as atividades de controle e prevenção são, muitas vezes, inadequadas ou inviáveis e a pasteurização do leite nem sempre é realizada. Nos países mais desenvolvidos os programas de controle e erradicação da tuberculose animal, somados à pasteurização de todo o leite destinado ao consumo humano, reduziram drasticamente a incidência da doença causada pelo M. bovis tanto nos animais como no homem (MIRANDA et al., 2008). Estimase que este agente seja responsável por até $2 \%$ dos casos de tuberculose humana nos países desenvolvidos e de 10 a 15\% nos países em desenvolvimento (FAO, 2012).

As principais vias de transmissão da doença dos bovinos para humanos são a aerógena, por inalação de aerossóis ao contato direto com animais ou carcaças infectadas, e a via digestiva, pelo consumo de leite e produtos lácteos não fervidos ou pasteurizados e com menor frequência pelo consumo de carne crua (MODA et al., 1996; THOEN et al., 2006). A transmissão transcutânea é mais rara e autolimitante, podendo ocorrer no contato direto com carcaças infectadas (GRANGE, 2001). Os empregados de frigoríficos, tratadores, ordenhadores, produtores rurais, veterinários, pessoal de laboratório e empregados de 
zoológicos são classes de maior risco, podendo manifestar a doença principalmente na forma pulmonar (THOEN et al., 2006).

A tuberculose humana causada por M. bovis é clínica, radiológica e patologicamente indistinguível da causada pelo M. tuberculosis. A diferenciação entre as espécies só é possível mediante o cultivo em meios de cultura e testes bioquímicos específicos ou utilização de técnicas de biologia molecular como a genotipagem (de La RUA-DOMENACH, 2006). Dessa forma, a dificuldade de diagnóstico diferencial associada à inexistência de métodos simples e acessíveis raramente permite quantificar ou conhecer a real proporção de casos da doença pelo M. bovis na população humana (GRANGE, 2001). Contudo, sabe-se que prevalência da tuberculose humana por $M$. bovis está diretamente relacionada a vários fatores, como proximidade da população com rebanhos bovinos, prevalência da tuberculose bovina, medidas de controle, condições socioeconômicas, hábitos alimentares e a própria higiene alimentar (MODA et al., 1996). Em estudo realizado na Alemanha foi encontrada uma prevalência de $0,2 \%$ de tuberculose humana causada por $M$. bovis nas cidades médias, de $1,4 \%$ nas cidades pequenas, enquanto no campo a prevalência média encontrada foi de $17,1 \%$ (SCHIMIEDEL, 1968). Barrera e Kantor (1987) em estudo semelhante realizado entre 1982 a 1984 na Argentina, onde a tuberculose bovina é relativamente alta e o diagnóstico bacteriológico da tuberculose humana é realizado com frequência, demonstraram que a tuberculose bovina constituía, em média, $0,5 \%$ de todos os casos humanos diagnosticados por isolamento e identificação do agente, chegando a atingir 6,2\% na Província de Santa Fé, uma zona rural onde se concentra a maior parte do efetivo bovino do país (SEQUEIRA et al., 1990). Além disto, vários estudos também mostram que o controle da tuberculose nas populações bovinas reduziu drasticamente a prevalência e a incidência da infecção humana por M. bovis nas mesmas regiões (GRANGE \& YATES, 1994; GRANGE, 1995).

Dados da Holanda ilustram bem a importância da tuberculose bovina na saúde humana: antes da erradicação da doença (no período de 1933 a 1939), a porcentagem de tuberculose humana causada por M. bovis variava entre 9,6\% (tuberculose pulmonar) e 24,0\% (tuberculose extrapulmonar); após a erradicação (no período de 1946 a 1949), essas proporções reduziram para $1,5 \%$ e $3 \%$ respectivamente, sendo que todos os casos de tuberculose pulmonar por M. bovis foram detectados em crianças, enquanto a tuberculose extrapulmonar atingiu apenas adultos (MEYN, 1953 apud VELOSO, 2014).

O Brasil ocupa a $18^{\mathrm{a}}$ posição em lista de países com mais casos de tuberculose, representando $0,9 \%$ dos casos estimados no mundo e 33\% dos estimados para as Américas, 
sendo registrados, entre 2005 e 2014, uma média de 70 mil casos novos e 4.400 mortes por ano (SVS-MS, 2016). Entretanto, não existem dados disponíveis sobre a ocorrência de tuberculose humana causada por $M$. bovis no país. A falta de notificação talvez se deva ao fato de que poucos laboratórios que cultivam micobactérias utilizam na rotina meios de cultura contendo piruvato, específico para cultivo do agente (SOBRAL et al., 2011).

No contexto da economia em saúde, os custos financeiros, representados pela prevenção, diagnóstico e tratamento da tuberculose humana, embora difíceis de serem mensurados, são reconhecidamente elevados, e a quebra da transmissão da doença nos grupos de risco tem consequências econômicas e sociais importantes (COSTA et al., 2005; ARAÚJO, 2009 apud GOMES, 2013). No Brasil, considerando somente recursos provenientes do Fundo Global, uma parceria público-privada dedicada a captar e desembolsar recursos para a prevenção e tratamento da AIDS, tuberculose e malária em todo o mundo, são investidos anualmente cerca de 21 milhões de dólares no combate à tuberculose (THE GLOBAL FUND, 2016).

Nas décadas de 1990 e 2000, os países desenvolvidos voltaram a se preocupar com a tuberculose bovina em razão de: (a) sua reemergência, decorrente do processo de imigração de pessoas oriundas de regiões onde a tuberculose bovina ainda é prevalente; (b) sua ocorrência em pacientes aidéticos, incluindo o aparecimento de cepas de M. bovis multidroga resistentes (MRD) nestes pacientes; (c) dos focos da doença em mamíferos silvestres e domésticos, com risco de transmissão ao homem; e (d) transmissão, pela via aérea, da doença aos tratadores de animais e funcionários de indústrias de carne. Nos países em desenvolvimento, a situação da tuberculose bovina é ainda mais preocupante, a exemplo de várias nações africanas, onde a doença, associada às epidemias de AIDS, apresenta elevados níveis de ocorrência nos animais (THOEN, LOBUE \& KANTOR, 2006). Nestes países as condições de transmissão são agravadas pela grande vulnerabilidade proporcionada pela pobreza e pelo reduzido acesso aos serviços de saúde, além da escassez de estudos que investigam a prevalência da tuberculose por M. bovis nas comunidades rurais (MICHEL, MÜLLER \& VAN HELDEN, 2010).

Outro impacto da tuberculose bovina, difícil de ser avaliado quantitativamente, diz respeito aos transtornos psicossociais, representados pela angústia, estresse e outros males, dos produtores e das comunidades rurais, diante do quadro de devastação, de rebanhos inteiros muitas vezes formados em fazendas familiares ao longo de muitas gerações. Um estudo na Inglaterra a partir de uma amostra de 50 produtores entrevistados nas regiões Sul e 
Oeste do país revelou que 30 tiveram sua vida cotidiana afetada pelas ações de controle da tuberculose bovina, 20 a vida de suas famílias e 10, a de seus empregados. Um questionário elaborado para identificação de distúrbios psiquiátricos demonstrou que produtores com restrição de movimentação de seus animais por longo período devido à doença mostraram níveis consideravelmente elevados de estresse comparados àqueles que não passaram pela experiência de foco em seus rebanhos (DEFRA, 2016).

A adoção de medidas sanitárias integradas envolvendo os diferentes segmentos da saúde animal e da saúde humana, com investimentos suficientes em programas de controle da tuberculose bovina pode proporcionar uma ampla abordagem da epidemiologia da doença e atenuar a incidência de $M$. bovis nos animais e no homem (JORGE, 2011). 


\section{OBJETIVOS}

\section{OBJETIVO GERAL:}

Caracterizar a situação epidemiológica e subsidiar o planejamento do controle da tuberculose bovina no Distrito Federal.

\section{OBJETIVOS ESPECÍFICOS:}

- $\quad$ Estimar a prevalência de focos de tuberculose bovina no Distrito Federal

- Estimar a prevalência da tuberculose bovina em fêmeas bovinas adultas no Distrito Federal

- Identificar fatores de risco associados à presença da doença nos rebanhos bovinos do Distrito Federal 


\section{REFERÊNCIAS BIBLIOGRÁFICAS}

AAGAARD, C., GOVAERTS, M., MEIKLE, V., GUTIÉRREZ-PABELLO, J.A., MCNAIR, J., ANDERSEN, P., SUÁREZ-GÜEMES, F., POLLOCK, J., ESPITIA, C. E CATALDI, A. (2010). Detection of bovine tuberculosis in herds with different disease prevalence and influence of paratuberculosis infection on PPDB and ESAT-6/CFP10 specificity. Preventive Veterinary Medicine, 96: 161-169.

ABALOS, P. E RETAMAL, P. (2004). Tuberculosis: una zoonosis re-emergente? Rev. sci. tech.Off. int. Epiz., 23 (2): 583-594.

ABBAS, A.K.; LICHTMAN, A.H.; POBER, J.S. (Eds.) Imunologia Celular e Molecular. $4^{\text {a }}$ Edição. Rio de Janeiro: Livraria e Editora Revinter, 2002. 544p

ABRAHÃO, R. M. C. M. Tuberculose humana causada pelo Mycobacterium bovis: considerações gerais e a importância dos reservatórios animais. Archives of Veterinary Science, v. 4, n. 1, p. 5-15, 1999

ACHA, P.N. \& SZYFRES, B. 2003. Zoonosis y enfermedades transmisibles comunes al hombre y a los animales: Bacteriosis y micosis. Vol.2. 3rd. ed. PAHO, Washington, DC. $396 \mathrm{p}$.

ALEXANDER, K.A., LAVER, P.N., MICHEL, A.L., WILLIAMS, M., VAN HELDEN, P.D., WARREN, R.M. e van PITTIUS, N.C. (2010). Novel Mycobacterium tuberculosis complex pathogen, M. mungi. Emerging Infectious Diseases, 16 (8): 1296-1299.

ALMEIDA, R.F.C. Teste diagnósticos in vivo, in vitro e investigação epidemiológicos da tuberculose bovina. 2004, 56f. Dissertação (Mestrado). Universidade Federal de Mato Grosso do Sul. Campo Grande. Mato Grosso do Sul.

Álvarez, J., DE JUAN, L., BEZOS, J., ROMERO, B., SÁEZ, J.P., MARQUÉS, S., DOMINGUÉZ, C., MÍNGUEZ, O., FERNÁNDEZ-MARDOMINGO, B., MATEOS, A., DOMÍNGUEZ, L. E ARANAZ, A. (2009). Effect of paratuberculosis on the diagnosis of bovine tuberculosis in a cattle herd with a mixed infection using interferon-gamma detection assay. Veterinary Microbiology, 135: 389-393

ALVES, C.M., GONÇALVES, V.S.P., MOTA, P.M.P.C; LAGE, A.P. Controle da tuberculose bovina. Cadernos Técnicos de Veterinária e Zootecnia, v.59, p. 69-81, 2008.

ARAÚJO, D. V. Custo e gerenciamento de doenças. In: ZUCCHI, P.Guia de economia e gestão de serviços de saúde. Manole, 2009. cap. 17, p. 375-386.

BAPTISTA, F., MOREIRA, E.C., SANTOS, W. L. M., NAVEDA, L.A.B. Prevalência da tuberculose em bovinos abatidos em Minas Gerais. Arquivo Brasileiro de Medicina Veterinária e Zootecnia, v. 56, p. 577-580, 2004.

BARRERA, L.; DE KANTOR, I.N. Non tuberculous mycobacteria and Mycobacterium bovis as a cause of human disease in Argentina. Trop Geogr Med. v. 39, p. 222-227, 1987. 
BARRY, C., CORBETT, D., BAKKER, D., ANDERSEN, P., MCNAIR, J E STRAIN, S. The Effect of Mycobacterium avium Complex Infections on Routine Mycobacterium bovis Diagnostic Tests. Veterinary Medicine International, doi:10.4061/2011/145092, 2011.

BARWINEK, F.; TAYLOR, N. M. Assessment of the socio-economic importance of bovine tuberculosis in Turkey and possible strategies for control or eradication. Ankara: Turkish-German Animal Health Information Projekt, 1996.

BELCHIOR, A. P. C.; LOPES, L. B.; GONÇALVES, V. S. P.; LEITE, R. C. Prevalence and risk factors for bovine tuberculosis in Minas Gerais State, Brazil. Tropical Animal Health and Production, Edinburg, v. 48, n.2, p. 373-78, 2016.

BERNUÉS, A.; MANRIQUE, E.; MAZA, M.T. Economic evaluation of bovine brucellosis and tuberculosis eradication programmes in a mountain area of Spain. Preventive Veterinary Medicine, v. 30, p. 137-49, 1997

BOLADO-MARTÍNEZ, E., BENAVIDES-DÁVILA， I., CANDIA- PLATA, M.d.C., NAVARRO-NAVARRO, M., AVILÉS-ACOSTA, M., ÁlVAREZ- HERNÁNDEZ., G. Proposal of a Screening MIRU-VNTR Panel for the Preliminary Genotyping of Mycobacterium bovis in Mexico. Hindawi Publishing Corporation BioMed Research International. Volume 2015, Article ID 416479, 7 pages, 2014.

BRASIL. Ministério da Agricultura, Pecuária e Abastecimento, Brasília. Manual Técnico do Programa Nacional de Controle e Erradicação da Brucelose e da Tuberculose Animal PNCEBT. Brasília-DF, 184p, 2006.

BUDDLE B.M., SKINNER M.A., WEDLOCK D.N., COLLINS D.M. \& LISLE G.W. 2002a. New generation vaccines and delivery systems for control of bovine tuberculosis in cattle and wildlife. Veterinay Immunology and Immunopathology. 87(2002):177185.

CAGIOLA, M.; FELIZIANI, F.; SEVERI, G.; PASQUALI, P.; RUTILI, D. Analysis of Possible Factors Affecting the Specificity of the Gamma Interferon Test in Tuberculosis-Free Cattle Herds. Clinical and Diagnostic Laboratory Immunology, v.11, n. 5, p.952- 56, 2004.

CASSIDY J.P. The pathogenesis and pathology of bovine tuberculosis with insights from studies of tuberculosis in humans and laboratory animal models. Vet. Microbiol., v.112, p.151-161, 2006.

CASTRO, K.G.; et al. Tuberculose bovina: diagnóstico, controle e profilaxia. PUBVET. Londrina. vol. 3, n. 30, Ed. 91, Art. 648. 2009.

CLEAVELAND, S; SHAW, D. J.; MFINANGA, S. G. SHIRIMA, G.; KAZWALA, R. R., EBLATE, E.; SHARP, M. Mycobacterium bovis in rural Tanzania: Risk factors for infection in human and cattle populations. Tuberculosis, Edinburgh, v. 87, p. 30-43, 2007.

COLLINS, J.D. (2011). Advances in molecular diagnostics for Mycobacterium bovis. Veterinary Microbiology, 151: 2-7. 
COOK, A. J.; TUCHILI, L.; M.; BUVE, A.; FOSTER, S. D.; GODFREY-FAUSETT, P.; PANDEY, G. S.; MCADAM, K. P. Human and bovine tuberculosis in the monze district of zambia-a cross- sectional study. British Veterinary .Journal, London, v. 152, n. 1, p. 37-46,

CORNER, L.A . Post mortem Diagnosis of Mycobacterium bovis Infection in cattle. Veterinary Microbiology, v. 40, n.1-2, p. 53- 63, 1994.

CORNER, L.A. (2006). The role of wild animal populations in the epidemiology of tuberculosis in domestic animals: how to assess the risk. Veterinary Microbiology, 112 (24): $303-312$.

COSIVI, J.M.; et al. Zoonotic Tuberculosis due to Mycobacterium bovis in Developing Countries. Emerging Infectious Diseases. vol. 4, n. 1, [January - March], 1998.

COSIVI, O.; GRANGE, J. M.; DABORN, C. J.; RAVIGLIONE, M. C.; FUJIKURA, T.; COUSINS, D.; ROBINSON, R. A.; HUCHZERMEYER, H. F.; DE KANTOR, I.; MESLIN, F. X. Zoonotic Tuberculosis due to Mycobacterium bovis in Developing Countries Emerging Infectious Diseases, Atlanta, v. 4, n. 1, p. 59-70, Jan./Marc. 1998.

COSTA, J. G.; SANTOS, C. A.; RODRIGUES, L. C.; BARRETO, M. L.; ROBERTS, J.A. Tuberculose em Salvador: custos para o sistema de saúde e para as famílias. Revista de. Saúde Pública, v. 39, n. 1, p. 122-128, 2005.

DANNENBERG A.M. Pathogenesis of pulmonary Mycobacterium bovis infection: basic principles established by the rabbit model. Tuberculosis, v.81, p.87-96, 2001.

de La RUA-DOMENECH, R. Human Mycobacterium bovis infection in the United Kingdom: Incidence, risks, control measures and review of the zoonotic aspects of bovine tuberculosis. Tuberculosis, v.86, n.2, p.77-109, 2006.

de MENDOZA, J.H., PARRA, A., TATO, A., ALONSO, J.M., REY, J.M., PEÑA, J., GARCÍA-SÁNCHEZ, A., LARRASA, J., TEIXIDÓ, J., MANZANO, G., CERRATO, R., PEREIRA, G., FERNÁNDEZ-LLARIO, P. E DE MENDOZA, M.H. Bovine tuberculosis in wild boar (Sus scrofa), red deer (Cervus elaphus) and cattle (Bos taurus) in a Mediterranean ecosystem (1992-2004). Preventive Veterinary Medicine, 74: 239-247, 2006.

DEFRA - Department for Environment, Food and Rural Affairs. Bovine TB. Badger control policy: value for money analysis 2016. U.K., GOV.UK, 2016. Acessado em 19.11.2016.

DENNY, G.O.; WILESMITH, J.W. Bovine tuberculosis in Northern Ireland, a case- control study of herd risk factors. Vet. Record., v.144, p.305-310, 1999.

DOHERTY ML, BASSETT HF, QUINN PJ, DAVIS WC, KELLY AP, MONAGHAN ML. A sequential study of the bovine tuberculin reaction. Immunology, v. 87, p. 9-14, 1996.

DUARTE, L.F.C. Investigação de Mycobacterium bovis em bovinos abatidos no município de Feira de Santana, Bahia. 2010, 61f. Dissertação (Mestrado). Escola de Medicina Veterinária da Universidade Federal da Bahia. Salvador. Bahia. 
DVORSKA, L., MATOLVA, L., BARTOS,M., PARMOVA, I., BARTIL, J., SVASTOVA, P., BULL. T.J. E PAVLIK, I. (2004). Study of Mycobacterium avium complex strains isolated from cattle in Czech Republic between 1996 and 2000. Veterinary Microbiology, 99: 239250 .

FAO - Food and Agriculture Organization of the United Nations. Animal Production and Health Division. Bovine tuberculosis at the animal-human-ecosystem interface. EMPRES Transboundary Animal Diseases Bulletin n. 40, 11p., 2012.

FERREIRA NETO, J.S. \& BERNARDI, F. O controle da tuberculose bovina. Higiene Alimentar, v. 11, p. 9-13, 1997.

FERREIRA NETO, J.S., BERNARDI, F. (2008). O controle da tuberculose bovina. Revista Higiene Alimentar. Disponível em http://www.bichoonline.com.br/artigos/ha0008.htm>. Acesso em 19/11/2016.

FIFIS, T., ROTHEL, J.S. \& WOOD,P.R. Soluble Mycobacterium bovis protein antigens: studies on their purification and immunological evaluation. Veterinary Microbiology. v.40, p.65-81, 1994.

FIGUEIREDO, S.M. Brucelose e Tuberculose Bovina no Estado da Paraíba: Estudo Retrospectivo. Mestrado em Medicina Veterinária - Centro de Saúde e Tecnologia Rural. Universidade Federal de Campina Grande, Paraíba. 2010. 53f.

GOMES, M. P. Análise de custo-efetividade do tratamento supervisionado e autoadministrado da tuberculose. 2013. 171 f. Dissertação (Mestrado) - Faculdade de Medicina de Ribeirão Preto, Universidade de São Paulo, Ribeirão Preto, 2013.

GONÇALVES, V.S.P. Programas de controle e erradicação da tuberculose bovina. In: LAGE, A.P., LOBATO, F.C.F.; MOTA, P.M.P.C.; GONÇALVES, V.S.P. Atualização em Tuberculose Bovina. Belo Horizonte: FEP-MVZ, 1998. p. 53-59.

GOODCHILD, A.V. E CLIFTON-HADLEY, R.S. (2001). Cattle-to-cattle transmission of Mycobacterium bovis. Tuberculosis, 81 (1/2): 23-41

GORMLEY, E., DOYLE, M.B., FITZSIMONS, T., MCGILL, K. E COLLINS, J.D. (2006). Diagnosis of Mycobacterium bovis infection in cattle by use of the gamma-interferon (Bovigam) assay. Veterinary Microbiology, 112: 171-179.

GRANGE, J.M. (2001). Mycobacterium bovis infection in human beings. Tuberculosis, 81 (1/2): 71-77.

GRANGE, J.M. Human aspects of Mycobacterium bovis infection. In: THOEN, C.O., STEELE, J.H. Mycobacterium bovis infection in animals and humans. Ames: Iowa State University Press, 1995. p. $29-46$.

GRANGE, J.M., YATES, M.D., Zoonotic aspects of Mycobacterium bovis infection. Vet. Microbiol. v.40, n.1-2, p.137- 151, 1994. 
GRIFFIN, J.M., MARTIN, S.W., THORBUM, M.A., EVES, J.A. E HAMMOND, R.F. (1996). A case control study on the association of selected risk factors with the occurrence of bovine tuberculosis in the Republic of Ireland. Preventive Veterinary Medicine, 27: 217229.

HADDAD D.J., IDE J., FERRAZOLI L., SEISCENTO M., TELLES M.A.S., MARIA MARTINS C., LEITE O.M., UEKI SYM. Micobacterioses: Recomendações para o diagnóstico e tratamento. Secretaria Estadual de Saúde de São Paulo. Coordenadoria de Doenças Infecciosas, 2005. p.29.

HARBOE, M., WIKER, H.G., DUNCAN, J.R. et al. Protein G-based Enzyme-Linked Immunosorbent Assay for Anti-MPB70 antibodies in Bovine Tuberculosis. Journal of Clinical Microbiology. v.28, p.913-921, 1990.

HEINEMANN, M.B., MOTA, P.M.P.C., LOBATO, F.C.F., LEITE, R.C., LAGE, A.P. Tuberculose bovina: uma introdução à etiologia, cadeia epidemiológica, patogenia e sinais clínicos. Cadernos Técnicos de Veterinária e Zootecnia, v. 59, p. 1-12, 2008.

HUMBLET, M.F., BOSCHIROLI, M.L., SAEGERMAN, C. Classification of worldwide bovine tuberculosis risk factors in cattle: a stratified approach. Vet Res. 2009 Sep-Oct; 40(5):50. Epub6 Jun, 2009. Review. PubMed PMID: 19497258; PubMed Central PMCID: PMC2710499.

JORGE, K.S.G. Identificação de Mycobacterium bovis em bovinos e sua importância na ocorrência de tuberculose zoonótica. 2011, 69p. Tese (Doutorado). Universidade Federal de Mato Grosso do Sul. Campo Grande: Mato Grosso do Sul.

JÚNIOR, M.E.K. \& SOUSA, C.L.M. Considerações sobre a tuberculose bovina no norte Fluminense e no município de Campos dos Goytacazes após o advento do PNCEBT - Programa Nacional de Controle e Erradicação da Brucelose e Tuberculose Bovina. Perspectivas on line. Vol. 2, n. 8, ano 2008

KANEENE, J. B., PFEIFFER, D. Epidemiology of Mycobacterium bovis. In: THOEN, C. O., STEELE, J. H., GILSDORF, M. J. Mycobacterium bovis infection in animals and humans. Blackwell Publishing. Ames, 2006. p. $34-48$

KANTOR, I.N. \& RITACCO, V. An update on bovine tuberculosis programmes in Latin American and Caribbean countries. Veterinary Microbiology, v.112, n.2-4, p.111-118, 2006.

KANTOR, I.N. \& RITACCO, V. Bovine tuberculosis in Latin America and the Caribbean: current status, control and eradication programs. Veterinary Microbiology, v.40, n.1-2, p.514,1994

KAZWALA, R. R., KAMBARAG,E D. M., DABORN, C. J., NYANGE, J., JIWA, S. F. H., SHARP, J. M. Risk factors associated with the occurrence of bovine tuberculosis in cattle in the Southern Highlands of Tanzania, Veterinary Research Communications, Amsterdam, v. 25, p. 609-614, 2001. 
LAGE, A.P., LOBATO, F.C.F., MOTA, P.M.P.C., GONÇALVES, V.S.P. Atualização em tuberculose bovina. Belo Horizonte: FEP-MVZ, 1998. 65p

LILENBAUM, W. Atualização em tuberculose bovina. Revista Brasileira de Medicina Veterinária, v. 22, n. 4, p. 145-151, 2000.

LILENBAUM, W. SOUZA, G.N., FONSECA, L.S. Management factores associated with bovine tuberculosis on dairy herds in Rio de Janeiro, Brazil. Revista Brasileira de Medicina Veterinária, v. 14. N. 2, p. 98-100, 2007.

LÔBO J.R. 2008. Análise custo-benefício da certificação de propriedades livres de tuberculose bovina. Dissertação de Mestrado em Agronegócios, Universidade de Brasília, Brasília, DF. 84p.

LOPES FILHO, P.B. Perfil epidemiológico da tuberculose bovina no Laboratório Nacional Agropecuário de Minas Gerais, 2004 a 2008. 2010, 41p. Dissertação (Mestrado). Universidade Federal de Minas Gerais. Escola de Veterinária. Belo Horizonte: Minas Gerais.

MENZIES, F.D. \& NEILL, S.D. (2000). Cattle-to-Cattle Transmission of Bovine Tuberculosis. The Veterinary Journal, 160: 92-106.

MEYN, A. 1953. Die Bekampfung der rindertuberkulose im bund und in den Ladern, land und hauswirtschaftlicher auswertungs und infirmationsdienst. 59:7-22.

MICHEL, A.L., MÜLLER, B. E VAN HELDEN, P. D. (2010). Mycobacterium bovis at the animal human interface: a problem, or not? Veterinary Microbiology, 140 (3-4): 371-381.

MILIAN-SUAZO, F; SALMAN, MD; RAMIREZ, C; PAYEUR, JB; RHYAN, JC; SANTILLAN, M. Identification of tuberculosis in cattle slaughtered in Mexico. Am. J. Vet. Res., v.61, p.86-9, 2000

MIRANDA, K.L., STYNEN, A.P.R., LAGE, A.P. Importância Zoonótica da Tuberculose Bovina. Cadernos Técnicos de Veterinária e Zootecnia, v. 59, p. 91-100, 2008

MODA, G., DABORN, C. J., GRANGE, J. M. E COSIVI, O. (1996). The zoonotic importance of Mycobacterium bovis. Tubercle and Lung Disease, 77: 103-108.

MONAGHAM, M.L. The tuberculin test . Veterinary Microbiology v.40 , p. 111-124, 1994 MOTA, P.M.P.C., ALENCAR, A.P., ASSIS, R.A., LOBATO, F.C.F., LAGE, A.P. Diagnóstico Alérgico da Tuberculose Bovina. Cadernos Técnicos de Veterinária e Zootecnia, v. 59, p.13-25, 2008.

MUNROE, F., DOHOO, I., MCNAB, W., SPANGLER, L. Risk factors for the between-herd spread of Mycobacterium bovis in Canadian cattle and cervids between 1985 and 1994. Preventive Veterinary Medicine, Amsterdam, v. 41, p. 119-133, 1999.

MYLREA, P.J. Erradication of bovine tuberculosis from New South Wales- A century of endeavour. Aust. Vet. J., 67: 104-107. 1990. 
NARANJO, V., GORTAZAR, C., VICENTE, J. E DE LA FUENTE, J. Evidence of the role of European wild boar as a reservoir of Mycobacterium tuberculosis complex. Veterinary Microbiology, 127: 1-9, 2008.

NISHI, J.S, SHURY, T., E ELKIN, B.T. Wildlife reservoirs for bovine tuberculosis (Mycobacterium bovis) in Canada: strategies for management and research. Veterinary Microbiology, 112 (2-4): 325-338, 2006.

O'REILLY, L.M. E DABORN, C.J. The epidemiology of Mycobacterium bovis infections in animals and man: a review. Tubercle and Lung Disease, Supplement 1, 76:1-46, 1995

OCEPEK, M., PATE, M., ZOLNIR-DOVC, M. E POLJAK, M. (2005). Transmission of Mycobacterium tuberculosis from Human to Cattle. Journal of Clinical Microbiology, 43 (7): 3555-3557.

OIE - Organización Mundial de Sanidad Animal - Manual de la OIE sobre Animales Terrestres, Tuberculosis Bovina, cap. 2.4.7, 2012.

OIE - Organización Mundial de Sanidad Animal - Portal WAHIS - Datos de Salud Animal. www.oie.int. Acessado em novembro de 2016.

OLIVEIRA, I.A.S., MELO, H.P.C., CAMARA, A., DIAS, R.V.C., SOTO-BLANCO,B. Prevalência de tuberculose no rebanho bovino de Mossoró, Rio Grande do Norte. Brazilian Journal of Veterinary Research and Animal Science, v. 44, n. 6, p. 395-400, 2007.

OLIVEIRA, P.R., REIS, D.O., RIBEIRO, S.C.A., SILVA, P.L., COELHO, H.E., LÚCIO, W. F., BARBOSA, F.C. Prevalência da tuberculose em carcaças e vísceras de bovinos abatidos em Uberlândia. Arquivo Brasileiro de Medicina Veterinária e Zootecnia, v. 38, n. 6, p. 965-971, 1986.

OLIVEIRA, V. M., FONSECA, A. H., PEREIRA, M. J. S., CARNEIRO, A. V., JESUS, V. L. T. ALVES, P. A. M. Análise retrospectiva dos fatores associados à distribuição da tuberculose bovina no estado do Rio de Janeiro. Arquivo Brasileiro de Medicina Veterinária e Zootecnia, Belo Horizonte, v. 60, n. 3. p. 574-579, 2008

OLOYA, J.,OPUDA-ASIBO, J., KAZWALA, R., DEMELASH, A.B., SKJERVE, E.; LUND, A.; JOHANSEN, T.B.; DJONNE, B. Mycobacteria causing human cervical lymphadenitis

pastoral communities in the Karamoja region of Uganda. Epidemiology and Infection, v.136, n.5, p.636-643, 2008.

PAIXÃO, T.A., BARBOSA, S.M., NETA, A.V.C., SANTOS, R.L. O diagnóstico postmortem da tuberculose bovina. Cadernos Técnicos de Veterinária e Zootecnia, v. 59, p.2642, 2008 .

PALMER, M.V. Tuberculosis: a reemerging disease at the interface of domestic animals and wildlife. Current Topics in Microbiology and Immunology, 315: 195-215, 2007 
PALMER, M.V. \& WATERS, W.R. Advances in bovine tuberculosis diagnosis and pathogenesis: What policy makers need to know. Veterinary Microbiology, 112: 181-190, 2006.

PALOMINO J.C., LEÃO S.C., RITACCO V. Tuberculosis 2007. From basic science to patient care. 1aria. Ed. Bourcillier Kamps. 2007. 687p. Disponível em www.Tuberculosis Textbook.com.

PHILLIPS, C.J.C., FOSTER, C.R.W., MORRIS, P.A., TEVERSON, R. The transmission of M. bovis infection to cattle. Research in Veterinary Science. v.74, p.1-15, 2003.

PLACKETT, P., RIPPER, J., CORNER, L.A. et al. An ELISA for the detection if anergic tuberculous cattle. Australian Veterinary Journal. v. 66, p.15-19, 1989.

POLLOCK J.M., RODGERS J.D., WELSH M.D., MCNAIR J. Pathogenesis of bovine tuberculosis: the role of experimental models of infection. Vet. Microbiol., v.112, p.141-150, 2006.

POLLOCK, J.M., WELSH, M.D. E McNAIR, J. (2005). Immune responses in bovine tuberculosis: Towards new strategies for the diagnosis and control of disease. Veterinary Immunology and Immunopathology, 108: 37-43.

PORPHYRE, T., STEVENSON M. A., MCKENZIE, J. Risk factors for bovine tuberculosis in New Zealand cattle farms and their relationship with possum control strategies. Preventive Veterinary Medicine, Amsterdam, v. 86, p. 93-106, 2008.

QUINN, P.J., CARTER, M.E., MARKEY, B. E CARTER, G.R. (2004). Mycobacterium species. In Clinical Veterinary Microbiology (pp. 156-169). Mosby, Elsevier Limited.

QUINN, P.J., MARKEY, M.E., LEONARD, F.C., FITZ PATRICK, E.S., FANNING, S. E HARTIGAN, P.J. (2011). Mycobacterium species. In Veterinary Microbiology and Microbial Disease, ( $2^{\text {nd }}$ edition). (Chapter 23). Blackwell Science Ltd.

RADOSTITS, O.M., GAY, C.C., HINCHCLIFF, K.W. E CONSTABLE, P.D. Diseases associated with Mycobacterium spp. In Veterinary Medicine: A textbook of the diseases of cattle, horses, sheep, pigs and goats. (10th edition). (pp. 1007-1044). Saunders Ltd., 2007.

RADOSTITS, O.M., GAY, C.C., BLOOD, D.C., HINCHCLIFF, K.W. Clínica Veterinária - um tratado de doenças de bovinos, ovinos, suínos, caprinos e equinos. 9 ed. Rio de Janeiro: Guanabara Koogan, 2002, 1737p.

REILLY, L.A. \& COURTENAY, O. Husbandry practices, badger sett density and habitat composition as risk factors for transient and persistent bovine tuberculosis on UK cattle farms. Preventive Veterinary Medicine, p. 129-142. 2007

RIET-CORREA, F. \& GARCIA, M. Tuberculose. In: RIET CORREA, F., SCHILD, A.L., MENDÉZ, M.C., LEMOS, R.A.A. (org). Doenças dos Ruminantes e Equinos. 2. ed. São Paulo: Varela Editora, 2001, v.1, p.351-362. 
RITACCO, V, LOPEZ, B, BARRERA,L, ERRICO, F, NADER, A, KANTOR, IN. Reciprocal cellular and immune responses in bovine tuberculosis. Res. Vet. Sci., v. 50, p.365$367,1991$.

RIVASTAVA, K., CHAUHAN, D.S., GUPTA, P., SINGH, H.B., SHARMA, V.D., YADAV, V.S., SREEKUMARAN., THAKRAL, S.S., DHARAMDHEERAN, J.S., NIGAM, P., PRASAD, H.K., KATOCH, V.M. Isolation of Mycobacterium bovis \& M. tuberculosis from cattle of some farms in north India--possible relevance in human health. Indian Journal of Medical Research, v. 128, n. 1, p. 26-31, 2008.

SAKAMOTO, S.M., ASSIS, R.A., ALENCAR, A.P., MOTA, P.M.P.C., LAGE, A.P. Métodos auxiliares de diagnóstico de tuberculose bovina. Cadernos Técnicos de Veterinária e Zootecnia, v. 59, p. 43-68, 2008.

SALAZAR, F. H. P. Ocorrência de tuberculose causada por Mycobacterium bovis em bovinos abatidos em frigoríficos no estado de Mato Grosso, Brasil. 2005. Dissertação (Mestrado)- Faculdade de Medicina Veterinária e Zootecnia, Universidade Federal de Mato Grosso do Sul, Campo Grande.

SCHILLER, I., VORDERMEIER, H.M., WATERS, W.R., CAGIOLA, M., WHELAN, A., PALMER, M.V., THACKER, T.C., MEIJLIS, J., CARTER, C., GORDON, S., EGNUNI, T., HARDEGGER, R., MARG-HAUFE, B., RAEBER, A. E OESCH, B. (2010). Comparison of tuberculin activity in the interferon gamma assay for the diagnosis of bovine tuberculosis. Vet. Rec. 167: 322-326.

SCHMIEDEL, A. Development and present state of bovine tuberculosis in man. Bull. Int. Union Tuberc., v. 40, p. 5-32, 1968.

SEQUEIRA, M. D, LATINI, O, LOPEZ, M, CECCONI, J. Tuberculosis bovina en seres humanos. Rev.Arg. Del Toráx. 51: 13- 17, 1990.

SKUCE R.A., ALLEN A.R. \& MCDOWELL, W.J. 2012. Herd-level risk factors for bovine tuberculosis: a literature review. Veterinay Medicine International. 2012:1-10.

SMITH B.P. Medicina Interna de Grandes Animais. 3aed. Editora Manole. 2006. 1728p.

SMITH, R.M., DROBNIEWSKI, F., GIBSON, A., MONTAGUE, J.D., LOGAN, M.N., HUNT, D., HEWINSON, G., SALMON, R.L., O'NEILL, B. Mycobacterium bovis infection, United Kingdom. Emerging Infectious Diseases, v.10, n.3, p.539-541, 2004.

SOBRAL, L. F., DUARTE, R. S., VIEIRA, G. B. O., DA SILVA, M. G., BOECHAT, N., FONSECA, L. S. Identificação de Mycobacterium bovis em cepas micobacterianas isoladas espécimes clínicos humanos em um complexo hospitalar na cidade do Rio de Janeiro. Jornal Brasileiro de Pneumonologia, Rio de Janeiro, v. 37, n. 5, p. 664-668, 2011.

SOUZA, A.V.S., SOUSA, C.F.S., SOUZA, R.M., RIBEIRO, R.M., OLIVEIRA, A.L. A importância da tuberculose bovina como zoonose. Disponivel em: $<$ http://www.bichoonline.com.br/artigos/ha0001.htm> Acesso em 12.11.2016. 
SVS-MS - Secretaria de Vigilância em Saúde Ministério da Saúde. Detectar, tratar e curar: desafios e estratégias brasileiras frente à tuberculose. Boletim Epidemiológico, V. 46, $\mathrm{N}^{\circ} 9,2015$.

THOEN, C., LOBUE, P. \& DE KANTOR I. 2006. The importance of Mycobacterium bovis as a zoonosis. Veterinary Microbiology. 112(2006):339-345.

THOEN, C.O., STEELE, J.H, GILSDORF, M.J. Mycobacterium bovis - infeccion in animals and humans. 2ed. Iowa: Iowa State University Press, 2006. p. 34-48, 68-83.

TIZARD I.R. Imunologia Veterinária - Uma Introdução. $6^{a}$ ed. São Paulo: Editora Roca, 2002.531p.

THE GLOBAL FUND, Brazil, Tuberculosis. Disponível em: ttp://www.theglobalfund.org/en/portfolio/country/?loc=BRA\&k=ac0dbc5d-1cca-454a-b02166c849fa8fcf. Acessado em dezembro/2016.

THOEN C.O. \& STEELE J.H. Mycobacterium bovis infection in animals and humans. Iowa State University Press. Ames, Iowa. 1995. 355p.

TIZARD, I.R. Imunologia Veterinária. Elsevier, São Paulo. 587p., 2009.

USA. Committee on Bovine Tuberculosis. Livestock Disease Eradication: Evaluation of the Cooperative State - Federal Bovine Tuberculosis Eradication Program. National Academy Press.Washington D.C., 1994.

VELOSO, F.P. Prevalência e fatores de risco da tuberculose bovina no Estado de Santa Catarina. Brasília: Faculdade de Agronomia e Medicina Veterinária, Universidade de Brasília, 2014, 31p. Dissertação de Mestrado.

WARDS, B. J., COLLINS, D. M., LISLE, G. W. Detection of Mycobacterium bovis in tissues by PCR. Veterinary Microbiology, v. 43, p. 227-240, 1995.

WHO, "World Health Organization global TB report (2014): Tuberculosis (TB)," Fact sheet 104, WHO, Geneva, Switzerland, 2014, http:/www.who.int/mediacentre/factsheets/fs104/en/.

WOBESER, G. Bovine Tuberculosis in Canadian Wildlife: An update history. Can Vet J, 50: 1169-1176. 2009.

WOOD, P. R, ROTHEL, J. S. In vitro immunodiagnostic assays for bovine tuberculosis. Veterinary Microbiology, Amsterdam, v. 40, p. 125-135, 1994.

ZANINI, M.S., MOREIRA, E.C., LOPES, M.T.P. et al. Mycobacterium bovis: polymerase chain reaction identification in bovine lymphonode biopsies and genotyping in isolates from southeast Brazil by spolygotyping and restricion fragment length polymorphism. Memórias do Instituto Oswaldo Cruz, v. 96, p. 1-5, 2001. 


\section{CAPÍTULO II}

\section{(Escrito na forma de artigo para publicação)}

\section{Prevalência e Fatores de Risco da Tuberculose Bovina no Distrito Federal, Brasil, 2015.}

\section{RESUMO}

A tuberculose bovina é uma doença crônica e infecciosa de ampla distribuição mundial, que afeta negativamente a produção pecuária, bem como o comércio nacional e internacional de animais e a saúde pública. Neste trabalho, estimou-se a prevalência aparente de rebanhos e de fêmeas adultas infectadas, assim como os fatores de risco associados à presença da tuberculose nos rebanhos do Distrito Federal. A amostragem abrangeu a população de rebanhos bovinos que apresentavam atividade reprodutiva subdivididos em duas subpopulações, sendo uma constituída por rebanhos menores, ou seja, com até 14 fêmeas adultas e outro de rebanhos maiores, com 15 ou mais fêmeas adultas. No total foram amostrados 344 rebanhos e testados 3.256 animais. A prova diagnóstica utilizada foi a tuberculinização intradérmica comparativa. A prevalência aparente em rebanhos e em fêmeas adultas foi estimada em 3,44\% [IC 95\%: 1,53-5,34] e 0,89\% [IC 95\%: 0,00-1,85], respectivamente. Apesar de não haver diferença estatisticamente significativa entre as prevalências estimadas para cada uma das subpopulações, foi observada a tendência de prevalências mais elevadas em rebanhos maiores, o que corrobora com os resultados encontrados em estudos anteriores conduzidos em outras unidades federativas do país. $\mathrm{O}$ modelo de regressão logística múltipla indicou como fator de risco associado à presença de tuberculose bovina, o resfriamento do leite na propriedade, com OR igual a 3,57 [IC 95\%: 1.01-12.6]. Esta variável está relacionada às propriedades leiteiras com algum grau de tecnificação, indicativo de produção mais intensiva associada normalmente aos sistemas de exploração do tipo confinado e semiconfinado, que favorecem o contato entre animais infectados e suscetíveis e a consequente transmissão da doença por via aerógena. Os resultados demonstraram que a tuberculose bovina tem prevalência baixa no Distrito Federal e a identificação do resfriamento do leite como fator de risco sugere que o risco da presença da enfermidade aumenta nas propriedades leiteiras que incorporam algum grau de tecnologia no sistema de produção. Estes resultados indicam que o Distrito Federal reúne condições para 
adotar sistemas de vigilância baseados em risco e para implementar programas de certificação de rebanhos livres, associados às indústrias de lácteos.

Palavras chave: Mycobacterium bovis, prevalência aparente, regressão logística múltipla, DF 


\begin{abstract}
Bovine tuberculosis is a chronic and infectious disease with a wide distribution worldwide, which negatively affects production, as well as national and international commerce of animals and public health. In this work, the apparent prevalence of infected adult females and herds was estimated, as well as the risk factors associated with the presence of tuberculosis in the herds of Distrito Federal. The sampling comprised the population of cattle with reproductive activity subdivided into two subpopulations, one of small herds, consisting of those that had up to 14 adult females and another of large herds, with a quantitative of 15 or more adult females. In total, 344 herds were sampled and 3,256 animals were tested. The diagnostic test used was comparative intradermal tuberculinization. The apparent prevalence in adult herds and females was estimated to be $3.44 \%$ [95\% CI: 1.53 5.34] and $0.89 \%$ [95\% CI: 0.00-1.85], respectively. Although a statistically significant difference between the estimated prevalences for each of the subpopulations was not confirmed, the tendency of higher prevalences in larger herds was observed, what corroborates the results found in previous studies performed in other federative units of the country. The multiple logistic regression model indicated as a risk factor associated with the presence of bovine tuberculosis, milk cooling on the property with OR of 3.57 [95\% CI: 1.0112.6]. This variable is related to the dairy properties with some degree of technification, indicative of more intensive production normally associated to the confined and semiconfined type of farming systems, favoring the contact between infected and susceptible animals and the consequent transmission of the disease through the aerial form. The results showed that bovine tuberculosis has a low prevalence in the Distrito Federal and the identification of milk cooling as a risk factor suggests that the risk of the presence of the disease increases in dairy farms that incorporate some degree of technology in the production system. These results indicate that Distrito Federal has conditions to adopt risk-based surveillance systems and to implement free herd certification programs, associated with the dairy industry.
\end{abstract}

INDEX TERMS: Mycobacterium bovis, apparent prevalence, multiple logistic regression, DF 


\section{INTRODUÇÃO}

Situado na região centro-oeste, o Distrito Federal é uma das 27 unidades federativas do país. É a menor unidade federativa brasileira e a única que não tem municípios, sendo dividida em 32 regiões administrativas, totalizando uma área de 5.779,999 km². Em seu território, está localizada a capital do Brasil, Brasília, que é também a sede do governo Federal. Apresenta a maior renda per capita do Brasil, estimada em R \$2.252,00 (IBGE, 2015) e ocupa a $8^{\mathrm{a}}$ posição na economia do país, com renda bruta de $\mathrm{R} \$ 62.859,43$ per capita (CODEPLAN-DF, 2013). Possui uma população de 2.977.216 habitantes (IBGE, 2016), com um elevado grau de exigência em qualidade e diversidade de produtos. No censo agropecuário de 2006 foram contabilizados 3.955 estabelecimentos agropecuários distribuídos em 251.578ha (IBGE, 2015), sendo que $82 \%$ das propriedades rurais têm menos de 20 ha. (EMATER-DF, 2008).

No segmento da pecuária bovina, em 2015, o rebanho era de 96.579 animais (IBGE, 2015), equivalente a $0,1 \%$ da população bovina da região Centro-Oeste, distribuídos em 3.004 propriedades (SEAGRI-DF, 2015). Essas propriedades são tipicamente pequenas e na sua grande maioria dedicadas à exploração leiteira ou mista (carne e leite) (FRANCISCO, 2008). Aproximadamente 50\% das propriedades que se dedicam à produção de leite nessa unidade da federação têm até 50 hectares de terra, e apenas $25 \%$ deles têm acima de 100 hectares (RIBEIRO et al., 2016).

Os produtores rurais do DF contam com programas institucionais com aporte de recursos tanto do governo local quanto federal, destinados à implementação de políticas públicas voltadas para o desenvolvimento do setor primário, abrangendo agricultura e pecuária. Parte destes recursos são oriundos de fundos públicos, mantidos pelo tesouro distrital, destinados a operações de crédito para investimentos e a indenizações em casos de abate ou sacrifício sanitário de animais previstos nos programas sanitários oficiais (SEAGRIDF 2016).

A tuberculose bovina é um grande problema de saúde animal em todo o mundo, afetando negativamente a produção pecuária, bem como o comércio nacional e internacional de animais (LAMINE-KHEMIRI, 2014). É uma das enfermidades que figuram no Código Sanitário para os Animais Terrestres da Organização Mundial de Saúde Animal (OIE) como doença de notificação obrigatória (OIE, 2016). Além disso, continua a ser um importante problema de saúde pública. Dados da Organização Mundial de Saúde mostram que a tuberculose humana registra mais de nove milhões de novos casos e 1,5 milhão de mortes por 
ano em todo o mundo (WHO 2014). Estima-se que M. bovis seja responsável por até 2\% dos casos de tuberculose humana nos países desenvolvidos e de 10 a 15\% nos países em desenvolvimento (FAO, 2012).

A importância do controle da tuberculose bovina no Brasil levou o Ministério da Agricultura, Pecuária e Abastecimento (Mapa) a instituir, em 2001, o Programa Nacional de Controle e Erradicação da Brucelose e da Tuberculose - PNCEBT (BRASIL, 2006). Nesta data, poucos estudos epidemiológicos sobre ambas as doenças haviam sido produzidos no país, a maioria daqueles relacionados à tuberculose restritos a regiões de estados ou municípios (LAENDER, 1978; CASTRO, 1979; ALFINITO; OLIVEIRA, 1986; LILENBAUM et al, 1998, BELCHIOR, 2016; POLETTO et al., 2004; BRASIL, 2006; OLIVEIRA et al., 2007). Frente à escassez de dados, o Mapa passou a fomentar a realização de estudos junto às Unidades Federativas com o objetivo de caracterizar a situação epidemiológica das duas enfermidades a nível nacional.

O Distrito Federal, em 2003, precedido por Minas Gerais (BELCHIOR et al., 2016), foi uma das primeiras Unidades Federativas a realizar o estudo da situação epidemiológica da tuberculose bovina, estimando prevalências de $0,36 \%$ em rebanhos e $0,05 \%$ em animais (RIBEIRO et al., 2016). Atualmente, onze outros estados já realizaram seus estudos: Bahia, Espirito Santo, Goiás, Mato Grosso, Mato Grosso do Sul, Paraná, Pernambuco, Rio Grande do Sul, Rondônia, Santa Catarina e São Paulo, apresentando, na grande maioria, prevalências baixas ou moderadas, com resultados que variaram entre 0,36\% (Distrito Federal) e 9,0\% (São Paulo) de propriedades positivas (focos).

O presente trabalho teve como objetivos estimar a prevalência e identificar fatores de risco associados à tuberculose em rebanhos bovinos e animais do DF após 13 anos do primeiro estudo transversal (RIBEIRO et al., 2016) da doença realizado na região, a fim de avaliar os resultados de combate à doença e planificar ações de defesa e vigilância voltadas para seu controle e erradicação, além de contribuir com subsídios para a gestão do PNCEBT.

\section{MATERIAL E MÉTODOS}

\section{Amostragem}

O estudo foi delineado por técnicos do Mapa, da USP e da UnB, em colaboração com a Secretaria de Estado da Agricultura, Abastecimento e Desenvolvimento Rural do Distrito Federal (SEAGRI-DF). 
A população-alvo do estudo foi constituída pelo conjunto das propriedades que apresentam rebanhos bovinos com atividade reprodutiva, ou seja, com fêmeas adultas de idade igual ou superior a 24 meses. Para descrever possíveis diferenças populacionais na prevalência da tuberculose bovina na região, optou-se por dividir as propriedades do DF em duas subpopulações e realizar dois processos amostrais independentes, um direcionado para as pequenas propriedades e outro para as grandes propriedades.

A subpopulação de pequenas propriedades foi constituída por aquelas que apresentavam um rebanho com menos de 15 fêmeas adultas em idade reprodutiva e a de grandes propriedades, por aquelas que possuíam 15 ou mais fêmeas na mesma condição. $\mathrm{O}$ ponto de corte de 15 fêmeas arbitrado para classificação dos rebanhos resultou da observação de que, no somatório de todas as propriedades, este valor representava o terceiro quartil da distribuição. Utilizou-se esta estratégia de amostragem para permitir a caracterização da tuberculose bovina nas duas subpopulações distintamente.

Do quadro amostral local de propriedades dedicadas à bovinocultura do Distrito Federal foram identificados 2.082 rebanhos pequenos e 645 rebanhos grandes, totalizando 2.727 rebanhos que possuíam fêmeas com atividade reprodutiva.

Os tamanhos amostrais para cada subpopulação estudada foram calculados segundo a fórmula descrita por Petrie \& Watson (2009), utilizando-se a ferramenta Epitools ${ }^{\circledR}$ (Sergeant 2015). O número mínimo de unidades primárias de amostragem (propriedades) estabelecido para a subpopulação de pequenos rebanhos foi de 226 propriedades, considerando o método de amostragem aleatória simples e os seguintes parâmetros: prevalência estimada $(\mathrm{P}=1,5 \%)$, precisão desejada (+/-1,5\%) e nível de confiança (95\%) para uma população alvo de 2.082 propriedades rurais. Para a subpopulação de grandes rebanhos o número mínimo de unidades primárias foi de 122 propriedades, considerando os seguintes parâmetros: prevalência estimada $(\mathrm{P}=2,5 \%)$, precisão desejada $(+/-2,5 \%)$ e nível de confiança $(95 \%)$ para uma população alvo de 645 propriedades.

Dentro de cada rebanho destas propriedades, foram amostradas aleatoriamente fêmeas com idade igual ou superior a 24 meses, que constituíram as unidades secundárias de amostragem. Esta faixa etária das unidades amostrais secundárias foi adotada devido ao delineamento para o estudo da brucelose bovina realizado concomitantemente a este estudo e por serem as fêmeas adultas a subpopulação de maior importância na dinâmica da doença; os mesmos animais foram testados para as duas doenças por uma questão logística e operacional.

Para o cálculo amostral das unidades secundárias de amostragem, assumiu-se uma 
prevalência intra-rebanho de 15\% (BELCHIOR et al., 2016) e valores de 77,5\% e 99,5\%, respectivamente, de sensibilidade e especificidade para o TCC (LÔBO,2008). Utilizando-se a ferramenta Epitools ${ }^{\circledR}$ (Sergeant 2015), foram executadas simulações com diferentes tamanhos de rebanhos e de amostras de animais e diferentes pontos de corte de forma a definir um número mínimo de animais do rebanho a serem amostrados que permitisse classificar a propriedade como positiva ou negativa para tuberculose bovina. $\mathrm{O}$ tamanho da amostra escolhido foi aquele que permitiu valores de sensibilidade e especificidade de rebanho, iguais ou superiores a 90\%. Assim, em rebanhos com até 99 fêmeas com idade igual ou superior a 24 meses, foram testadas 20 fêmeas; em rebanhos cujo total de fêmeas com idade igual ou superior a 24 meses era inferior a 20 fêmeas, amostrou-se a totalidade das fêmeas existentes; em rebanhos 100 ou mais fêmeas em reprodução, amostrou-se 40 fêmeas. Rebanhos com até 99 fêmeas que apresentassem pelo menos um animal reagente positivo foram considerados positivos; rebanhos com mais de 99 fêmeas somente foram considerados positivos se apresentassem dois animais reagentes dentre as 40 fêmeas testadas.

Foram excluídas da amostragem fêmeas em peri-parto, ou seja, com aproximadamente 15 dias anteriores ou 15 dias posteriores ao parto, uma vez que os animais neste período tendem a apresentar-se como potenciais falso-negativos aos testes de diagnóstico (BRASIL, 2006).

A seleção dos animais a serem amostrados foi realizada pelo método de amostragem aleatória simples ou sistemática, utilizando-se de tabela de números aleatórios e de acordo com o número de animais existentes e a ser amostrado por rebanho.

Nos casos de propriedades rurais com mais de um rebanho, foi escolhido como alvo do estudo o rebanho de maior importância econômica (corte, leite ou misto), no qual os animais estavam submetidos ao mesmo tipo de manejo, ou seja, sob as mesmas condições de risco.

\section{Diagnóstico de Tuberculose}

Como método de diagnóstico, foi empregada a prova de tuberculinização intradérmica cervical comparada (TCC), seguindo as normas do PNCEBT (BRASIL, 2006).

\section{Operacionalização}

As atividades de campo foram desenvolvidas no período de julho a dezembro de 2015, incluindo a realização dos testes de diagnóstico e a aplicação de um questionário 
epidemiológico em cada propriedade amostrada com finalidade de caracterizar as tipologias produtivas do DF e também identificar fatores de risco associados à tuberculose bovina. As variáveis pesquisadas também incluíram algumas questões de interesse em saúde pública. Os procedimentos operacionais de realização dos testes de diagnóstico e de aplicação do questionário foram conduzidos por médicos veterinários e auxiliares de campo do serviço oficial de defesa sanitária animal do Distrito Federal (SEAGRI-DF). Os médicos veterinários envolvidos receberam treinamento em métodos de diagnóstico e controle da tuberculose bovina a fim de assegurar a padronização dos procedimentos.

Os rebanhos foram identificados individualmente por um código de 10 dígitos e as propriedades foram localizadas por coordenadas geográficas, relacionadas em planilhas eletrônicas por subpopulação e por unidade operacional.

Quando, por algum motivo, foi necessário substituir alguma propriedade sorteada inicialmente, esta foi substituída pela subsequente na ordem cadastral das propriedades com fềmeas em idade reprodutiva, relacionadas por subpopulação e por região pecuária. Os procedimentos de substituição, bem como de comunicação às equipes de campo dos dados da nova propriedade couberam, exclusivamente, à coordenação central do estudo a fim de garantir a substituição por outra propriedade, pertencente à mesma subpopulação e à mesma região, evitando-se viés de seleção.

Um Termo de Compromisso foi firmado entre o proprietário e o serviço oficial à primeira visita, acordando sua participação sob o compromisso de colaborar na execução das atividades, manter os animais pelo tempo necessário à conclusão dos testes de diagnóstico e eliminar os animais reagentes positivos (por abate sanitário ou destruição na propriedade). Nas duas visitas subsequentes, procedia-se a realização dos testes de tuberculinização intradérmica comparada e a aplicação do questionário epidemiológico. Outras visitas eram agendadas para atividades de eliminação de animais com resultado positivo aos testes e para o reteste de animais com resultado inconclusivo, caso fossem necessários estes procedimentos.

As informações obtidas a campo a partir do questionário, bem como as medidas das espessuras das dobras da pele constantes das fichas de tuberculinização foram digitalizadas em banco de dados on line, desenvolvido e disponibilizado pelo Laboratório de Epidemiologia da Faculdade de Medicina Veterinária e Zootecnia da Universidade de São Paulo (VPS/FMVZ/USP) no endereço eletrônico: https://vps.fmvz.usp.br/tb.

Um mapa com a localização espacial dos rebanhos amostrados e dos rebanhos positivos foi elaborado com auxílio do software ArcGis, versão 10.0 (ERIS, 2012). 


\section{Análises Estatísticas}

A análise dos dados foi realizada no Laboratório de Epidemiologia Veterinária da Faculdade de Agronomia e Medicina Veterinária da Universidade de Brasília (Epiplan/FAV/UnB), com auxílio do software STATA ${ }^{\circledR}$, versão 12 (STATACORP, 2011).

Para cada subpopulação, a estimativa da prevalência de tuberculose em rebanhos baseou-se na razão entre propriedades classificadas como positivas na amostra e o total de propriedades amostradas na subpopulação. Para a estimativa da prevalência de propriedades com tuberculose (focos) em todo o Distrito Federal, considerou-se que a amostragem das propriedades em cada subpopulação não foi proporcional ao número de propriedades existentes nas respectivas subpopulações; portanto, as amostras de cada subpopulação contribuíram com pesos diferentes para o cálculo da prevalência distrital.

Uma vez que cada unidade amostral primária e secundária representa respectivamente um conjunto de propriedades e de animais dentro da amostra, foi necessário ponderar os resultados em relação à subpopulação e propriedade. Assim, o peso $(P l)$, exercido por cada propriedade amostrada em relação à subpopulação, para fins de cálculo de prevalência no DF, foi dado conforme a expressão:

\section{$P 1=\frac{\text { Número de propriedades existentes na subpopulação }}{\text { Número de propriedades amostradas na subpopulação }}$}

Para a estimativa da prevalência de tuberculose em animais, o cálculo considerou a amostragem de conglomerados feita em dois estágios. Assim, para o cálculo da prevalência distrital desta categoria animal, foi efetuada uma ponderação, considerando-se o peso P2 exercido por cada fêmea de idade igual ou superior a 24 meses amostrada em relação ao seu rebanho e, em seguida, na respectiva subpopulação:

$$
P 2=\frac{\text { Fêmeas } \geq 24 \text { meses na propriedade }}{\text { Fêmeas } \geq 24 \text { meses amostradas } n a} \quad \times \quad \frac{\text { Fêmeas } \geq 24 \text { meses na subpopulação }}{\text { propriedade }} \quad \begin{gathered}
\text { Fêmeas } \geq 24 \text { meses nas propriedades amostradas na } \\
\text { subpopulação }
\end{gathered}
$$

Como etapa inicial de identificação dos possíveis fatores de risco, após análise exploratória dos dados, as variáveis quantitativas foram convertidas em categóricas, para utilização na análise univariada e no modelo de regressão logística. Isto permitiu a discussão do efeito de cada categoria de cada variável analisada em relação à presença da doença no rebanho, facilitando a comunicação do risco em comparação à discussão individualizada do incremento de risco gerado pelo acréscimo de cada observação. Quando necessário, as variáveis qualitativas foram reagrupadas, e a categoria de prevalência mais baixa foi tomada como categoria de base para comparação e estimativa da Odds Ratio. Utilizando-se o teste do 
Qui-Quadrado $(\chi 2)$, procedeu-se a análise univariada das variáveis do questionário cuja associação com a presença ou ausência de tuberculose no rebanho apresentava plausibilidade biológica ou epidemiológica. Aquelas cujo nível de significância (p) foi igual ou menor a 0,20 foram submetidas ao modelo de regressão logística múltipla.

O método utilizado para obtenção de um modelo reduzido foi o de eliminação hierárquica (Hierarchical Backward Elimination), ficando no modelo final somente as variáveis que apresentaram o valor de $\mathrm{p} \leq 0,05$. O modelo foi elaborado no formato designbased, conforme sugerido por Hosmer, Lemeshow \& Sturdivant (2013). Este formato considera o peso de cada propriedade amostrada nas duas subpopulações de amostragem, fornecendo resultados mais adequados para inferência populacional do efeito dos fatores de risco.

\section{RESULTADOS}

\section{Amostragem}

O número de unidades primárias (propriedades) de amostragem de cada subpopulação foi distribuído de forma proporcional à quantidade de propriedades existentes em cada uma das cinco unidades operacionais do serviço oficial de defesa sanitária animal do Distrito Federal indicadas na Tabela 1:

Tabela 1. Distribuição das propriedades amostradas por subpopulação e região pecuária do Distrito Federal

\begin{tabular}{ccc|c|c}
\hline \multirow{2}{*}{$\begin{array}{c}\text { Unidade } \\
\text { Operacional } \\
\text { (Região }\end{array}$} & \multicolumn{2}{c|}{$\begin{array}{c}\text { Subpopulação de rebanhos } \\
\text { menores }\end{array}$} & \multicolumn{2}{c}{$\begin{array}{c}\text { Subpopulação de rebanhos } \\
\text { maiores }\end{array}$} \\
\cline { 2 - 5 } Pecuária) & \multicolumn{2}{c}{$\begin{array}{c}\text { Rebanhos com atividade } \\
\text { reprodutiva }\end{array}$} & \multicolumn{2}{c}{$\begin{array}{c}\text { Rebanhos com atividade } \\
\text { reprodutiva }\end{array}$} \\
\cline { 2 - 5 } & Existentes & Sorteados & Existentes & Sorteados \\
\hline Brazlândia & 434 & 47 & 110 & 21 \\
Gama & 550 & 60 & 150 & 28 \\
Planaltina & 384 & 42 & 111 & 21 \\
Rio Preto & 354 & 38 & 170 & 32 \\
Sobradinho & 360 & 39 & 104 & 20 \\
\hline TOTAL & 2.082 & 226 & 645 & 122 \\
\hline
\end{tabular}

\section{Prevalência de Rebanhos e Animais}

Foram amostradas 344 propriedades, sendo 229 com rebanhos pequenos e 115 com rebanhos maiores, e 3.256 animais. Dentre as 348 propriedades inicialmente sorteadas e 
trabalhadas, três foram desprezadas, em função de erros e inconsistências detectados no questionário epidemiológico e uma por se tratar de criação de bubalinos.

Algumas propriedades foram realocadas nas subpopulações em função da atualização do número de fêmeas adultas, observada durante a realização das atividades de campo.

A Tabela 2 mostra os dados censitários da população bovina do Distrito Federal e a amostragem por subpopulação (tamanho de rebanho) ao final do estudo.

Tabela 2. Dados censitários da população bovina do Distrito Federal, por tamanho de rebanho.

\begin{tabular}{ccc|cc}
\hline \multirow{2}{*}{$\begin{array}{c}\text { Tamanho } \\
\text { de }\end{array}$} & \multicolumn{2}{c|}{$\begin{array}{c}\text { Rebanhos com atividade } \\
\text { reprodutiva }\end{array}$} & \multicolumn{2}{c}{ Fêmeas com $\geq 24$ meses } \\
\cline { 2 - 5 } rebanho* & Existentes & Amostrados & Existentes & Amostradas \\
\hline Menores & 2082 & 229 & 10336 & 1075 \\
Maiores & 645 & 115 & 33337 & 2181 \\
\hline TOTAL & 2727 & 344 & 43673 & 3256
\end{tabular}

* Rebanhos menores apresentavam menos de 15 fêmeas com mais de 24 meses. Rebanhos maiores apresentavam 15 ou mais fêmeas com mais de 24 meses

Dos 344 rebanhos, 13 foram classificados como positivos para tuberculose, sendo 6 dentre os rebanhos menores e 7 dentre os rebanhos com 15 ou mais fêmeas. Dos 3.256 animais amostrados no Distrito Federal, 26 foram classificados como positivos. Dos 26 animais reagentes positivos, 7 pertenciam a rebanhos menores e 19 pertenciam a rebanhos maiores. Um rebanho com apenas uma fêmea reagente positiva dentre 40 testadas foi classificado como negativo para tuberculose.

Os cálculos de prevalência foram ponderados para respeitar as proporções reais de cada subpopulação. No presente estudo, cada propriedade amostrada na subpopulação de rebanhos maiores representou 9,1 propriedades, enquanto as unidades primárias de amostragem na subpopulação de rebanhos maiores representaram 5,6 propriedades.

Nas tabelas 3 e 4 encontram-se, respectivamente, as prevalências aparentes de rebanhos e de fêmeas com idade igual ou superior a 24 meses para tuberculose bovina, por tamanho de rebanho, no Distrito Federal. 
Tabela 3. Prevalência aparente de rebanhos para tuberculose bovina no Distrito Federal, por tamanho de rebanho.

\begin{tabular}{cccc}
\hline $\begin{array}{c}\text { Tamanho de } \\
\text { rebanho* }\end{array}$ & $\begin{array}{c}\mathrm{N}^{\mathrm{o}} \text { de rebanhos } \\
\text { positivos }\end{array}$ & Prevalência aparente (\%) & Intervalo de confiança (95\%) \\
\hline Menores & 6 & 2,62 & {$[0,96-5,61]$} \\
Maiores & 7 & 6,08 & {$[2,48-12,13]$} \\
\hline Total & 13 & 3,44 & {$[1,53-5,34]$}
\end{tabular}

*Rebanhos menores apresentavam menos de 15 fêmeas com mais de 24 meses. Rebanhos maiores apresentavam 15 ou mais fêmeas com mais de 24 meses

Tabela 4. Prevalência de tuberculose bovina em fêmeas com 24 meses ou mais no Distrito Federal, por tamanho de rebanho.

\begin{tabular}{cccc}
\hline $\begin{array}{c}\text { Tamanho de } \\
\text { rebanho* }\end{array}$ & $\begin{array}{c}\mathrm{N}^{\mathbf{o}} \text { de animais } \\
\text { positivos }\end{array}$ & Prevalência aparente (\%) & Intervalo de confiança (95\%) \\
\hline Menores & 7 & 0,57 & {$[0,09-1,05]$} \\
Maiores & 19 & 1,00 & {$[0,00-2,25]$} \\
\hline Total & 26 & 0,89 & {$[0,00-1,85]$}
\end{tabular}

*Rebanhos menores apresentavam menos de 15 fêmeas com mais de 24 meses. Rebanhos maiores apresentavam 15 ou mais fêmeas com mais de 24 meses

Os cálculos ponderados estimaram uma prevalência de 3,44 \% [IC 95\%: 1,53-5,34] de tuberculose em propriedades e 0,89\% [IC 95\%: 0,00-1,85] em fêmeas com idade igual ou superior a 24 meses de idade. As medidas pontuais de prevalências estimadas, por subpopulação, tanto em rebanhos quanto em animais revelaram ser mais elevadas na subpopulação constituída por rebanhos maiores, embora não se possa afirmar com $95 \%$ de confiança que haja diferença das prevalências entre as subpopulações com base nos intervalos de confiança. Na tabela 5 são demonstrados os números estimados de rebanhos infectados (positivos) existentes na população estudada considerando as medidas dos intervalos de confiança obtidos para as prevalências em rebanhos menores e maiores.

Tabela 5. Estimativa do número de rebanhos infectados no Distrito Federal

\begin{tabular}{|c|c|c|c|c|c|c|c|}
\hline \multirow{2}{*}{$\begin{array}{l}\text { Tamanho de } \\
\text { rebanho* }\end{array}$} & \multirow{2}{*}{$\begin{array}{l}\text { Rebanhos } \\
\text { cadastrados }\end{array}$} & \multicolumn{3}{|c|}{ Prevalência } & \multicolumn{3}{|c|}{$\begin{array}{l}\text { Número provável de rebanhos } \\
\text { infectados }\end{array}$} \\
\hline & & $\begin{array}{l}\text { Limite } \\
\text { inferior }\end{array}$ & $\begin{array}{l}\text { Valor } \\
\text { médio }\end{array}$ & $\begin{array}{l}\text { Limite } \\
\text { Superior }\end{array}$ & $\begin{array}{l}\text { Limite } \\
\text { inferior }\end{array}$ & $\begin{array}{l}\text { Valor } \\
\text { médio }\end{array}$ & $\begin{array}{l}\text { Limite } \\
\text { Superior }\end{array}$ \\
\hline Menores & 2.082 & 0,0096 & 0,0262 & 0,0561 & 20 & 55 & 117 \\
\hline Maiores & 645 & 0,0248 & 0,0608 & 0,1213 & 16 & 39 & 78 \\
\hline
\end{tabular}

*Rebanhos menores apresentavam menos de 15 fêmeas com mais de 24 meses e rebanhos maiores apresentavam 15 ou mais fêmeas com mais de 24 meses 
O Mapa 2.1 mostra, graficamente, a localização dos rebanhos amostrados e dos rebanhos positivos.

Mapa 2.1. Demonstrativo da distribuição espacial dos rebanhos amostrados e rebanhos positivos para tuberculose bovina no Distrito Federal

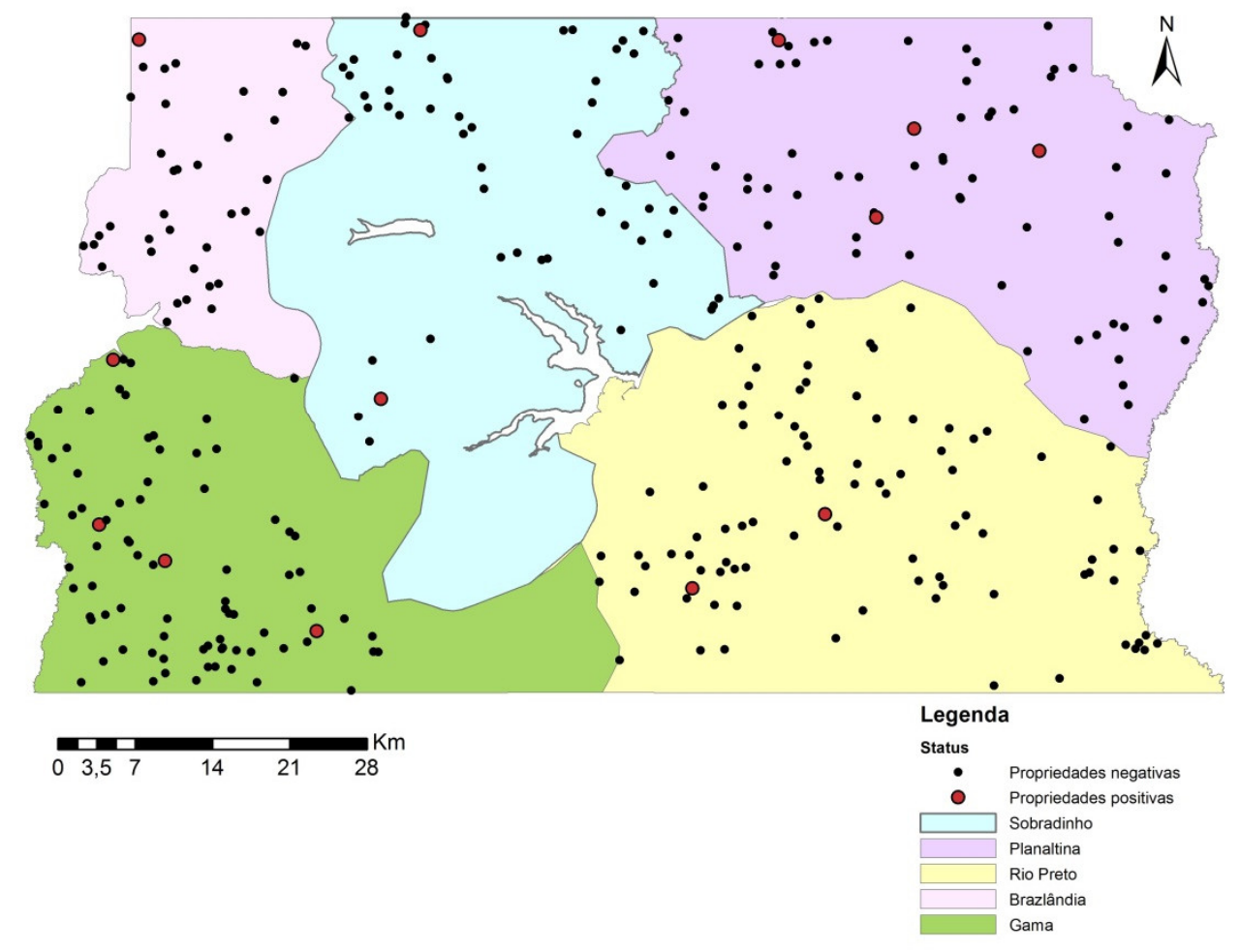

Todos os animais reagentes positivos foram sacrificados em estabelecimento de abate sob inspeção do serviço oficial do Distrito Federal.

\section{Análises de Fatores de Risco}

A tabela 6 traz as variáveis do questionário selecionadas para compor o modelo analítico de regressão logística, analisadas quanto à associação com a ocorrência de tuberculose em rebanhos do Distrito Federal. Devido ao baixo número de casos, as variáveis "confinado", "semiconfinado" e "extensivo" foram reagrupadas em duas categorias: "confinado ou semiconfinado" e "extensivo".

As variáveis relacionadas ao "tipo de exploração" e "tipo de sistemas de criação", apesar de apresentarem níveis de significância ( $\mathrm{p}$-valor) superiores a 0,20 foram mantidas 
para compor o modelo de regressão logística por representarem reconhecidos fatores de risco associados à ocorrência da tuberculose bovina.

Tabela 6. Análise univariada indicando variáveis com valor de $\mathrm{p} \leq 0,20$, testadas para associação com rebanhos positivos.

\begin{tabular}{|c|c|c|c|c|}
\hline Vari & vel & Casos & Controles & p-valor ${ }^{1}$ \\
\hline Tipo de exploração & & & & 0.285 \\
\hline & Corte & 0 & 48 & \\
\hline & Leite & 7 & 173 & \\
\hline & Misto & 6 & 110 & \\
\hline Tipo de sistema de criação & & & & 0.213 \\
\hline & Confinado ou & 9 & 171 & \\
\hline & semiconfinado & 4 & 160 & \\
\hline & Extensivo & & & \\
\hline $\mathrm{N}^{\mathrm{o}}$ de fêmeas do rebanho & & & & 0.112 \\
\hline & Até 14 fêmeas & 6 & 223 & \\
\hline & 15 fêmeas ou mais & 7 & 108 & \\
\hline $\mathrm{N}^{\mathrm{o}}$ de ordenhas por dia & & & & 0.066 \\
\hline & Não ordenha & 0 & 71 & \\
\hline & Uma ordenha & 10 & 230 & \\
\hline & Duas ordenhas ou mais & 3 & 30 & \\
\hline Tipo de ordenha & & & & 0.164 \\
\hline & Não ordenha & 0 & 71 & \\
\hline & Ordenha mecânica & 1 & 36 & \\
\hline & Ordenha manual & 12 & 224 & \\
\hline Presença de suínos & & & & 0.041 \\
\hline & Não & 3 & 172 & \\
\hline & Sim & 10 & 159 & \\
\hline Aluga Pasto & & & & 0.138 \\
\hline & Não & 8 & 261 & \\
\hline & Sim & 5 & 70 & \\
\hline Entrega leite & & & & 0.098 \\
\hline & Não & 8 & 266 & \\
\hline & Sim & 5 & 65 & \\
\hline Resfria leite & & & & 0.054 \\
\hline & Não & 9 & 290 & \\
\hline & Sim & 4 & 41 & \\
\hline Presença de felídeos silvestres & & & & 0.037 \\
\hline & Não & 10 & 307 & \\
\hline & Sim & 3 & 24 & \\
\hline
\end{tabular}

${ }^{1}$ p-valor ao Teste do Qui-Quadrado.

A única variável que permaneceu no modelo final foi "resfria leite", conforme apresentado na Tabela 7, no formato design-based de regressão logística (Hosmer, Lemeshow \& Sturdivant 2013), indicando a Odds Ratio e o intervalo de 95\% de confiança correspondente. 
Tabela 7. Modelo de regressão logística no formato design-based (Hosmer, Lemeshow \& Sturdivant (2013).

\begin{tabular}{cccc}
\hline Variável & Odds Ratio & IC 95\% & p-valor \\
\hline Resfria leite & 3.57 & {$[1.01-12.6]$} & 0,048 \\
\hline
\end{tabular}

De acordo com o resultado observado na tabela 7 , a chance de detecção de tuberculose em rebanhos de propriedades que resfriam leite foi 3,57 [IC 95\%: 1,01-12,6] vezes maior em relação aos rebanhos de propriedades que não adotavam esta prática, no Distrito Federal.

Das 344 propriedades amostradas, $296(86,05 \%)$ possuíam rebanhos leiteiros ou mistos, sendo que 251 destas não adotavam práticas de resfriamento do leite produzido. As propriedades que resfriavam leite totalizavam 45 , correspondendo a $13,08 \%$ das propriedades amostradas e 15,20\% das propriedades com alguma atividade leiteira. A descrição das propriedades que resfriam leite no Distrito Federal, encontra-se na Tabela 8. Das 13 propriedades com rebanhos positivos para tuberculose, quatro estão entre as 45 propriedades com atividade leiteira (leite ou mista) que resfriam leite.

Tabela 8. Descrição das propriedades que resfriam o leite no Distrito Federal, restrita àquelas que produzem leite (leite ou mistas)

\begin{tabular}{lcccc}
\hline & Variável & Não Resfriam & Resfriam & p-valor $^{1}$ \\
\hline Tipo de exploração & & & & 0.012 \\
& Leite & $145(58 \%)$ & $\mathbf{3 5}(\mathbf{7 7 . 8 \%})$ & \\
& Misto & $106(42 \%)$ & $10(22.2 \%)$ &
\end{tabular}

Tipo de sistema de criação $<0.000$

$\begin{array}{lcc}\text { Confinado ou } & & \\ \text { semiconfinado } & 123(49 \%) & \mathbf{4 1}(\mathbf{9 1 . 1 \%}) \\ \text { Extensivo } & 128(51 \%) & 4(8.9 \%)\end{array}$

$\mathrm{N}^{\circ}$ de fêmeas do rebanho $<0.000$

Até 14 fềmeas

$198(78.8 \%) \quad 8(17.8 \%)$

15 fêmeas ou mais

$53(21.2 \%) \quad 37(82.2 \%)$

$\mathrm{N}^{\circ}$ de vacas em lactação ${ }^{1}$

1 a 14 vacas

$204(89.4 \%) \quad 6(13.3 \%)$

15 vacas ou mais

$24(10.6 \%) \quad 39(86.7 \%)$ 
$\mathrm{N}^{\mathrm{o}}$ de ordenhas por dia ${ }^{1}$

Uma ordenha

Duas ordenhas ou mais
$220(96.4 \%) \quad 20(44.4 \%)$

$8(3.6 \%) \quad \mathbf{2 5}(\mathbf{5 5 . 5 6 \%})$

Tipo de ordenha ${ }^{1}$

$\begin{array}{lcc}\text { Ordenha manual } & 219(96 \%) & 17(37.8 \%) \\ \text { Ordenha mecânica } & 9(4 \%) & \mathbf{2 8}(62.2 \%)\end{array}$

23 propriedades mistas que não resfriam leite não estavam ordenhando no momento do inquérito.

As variáveis "número de vacas em lactação", "produção leiteira diária", "raça" e "tipo de sistema de criação" sugerem que a maioria dos rebanhos de produção leiteira no Distrito Federal, possui até 10 fêmeas adultas, sobretudo de raça mestiça. As propriedades produzem em média 50 litros de leite por dia. A média geral de produção por vaca é de 7,6 litros. O tipo de criação predominante é o semiconfinado, seguido pelo extensivo. $\mathrm{O}$ confinamento está presente em apenas $2,1 \%$ das propriedades.

\section{DISCUSSÃO E CONCLUSÕES}

As prevalências de rebanhos e de fêmeas adultas positivas para a tuberculose bovina estimadas por este estudo no Distrito Federal resultaram, respectivamente, em 3,44\% [IC 95\%: 1,53-5,34] e 0,89\% [IC 95\%: 0,00-1,85], sendo, em média, superiores às encontradas por Ribeiro et al., em estudo similar na mesma região conduzido em 2003, que demonstrou à época prevalências de 0,36\% [IC95\%: 0,0-2,0] em rebanhos e 0,05\%[IC95\%: 0,0-0,4] em animais. A diferença de prevalência observada entre os dois estudos é epidemiologicamente importante, porém a sobreposição dos intervalos de confiança indica que a diferença não é estatisticamente significativa.

As prevalências encontradas estão compatíveis com as estimadas por estudos conduzidos em outras Unidades Federativas do Brasil, como Bahia, Rondônia, Pernambuco, Mato Grosso, Mato Grosso do Sul, Rio Grande do Sul, Minas Gerais, Paraná e Goiás. Apresenta-se inferior às encontradas nos estados do Espírito Santo e São Paulo e superior à estimada em Santa Catarina (BAHIENSE et al., 2016.; BELCHIOR et al., 2016.; DIAS et al., 2016; GALVIS et al., 2016; GUEDES et al., 2016.; LIMA et al., 2016; NESPOLI et al., 2016.; QUEIROZ et al., 2016.; VELOSO et al., 2016.; VENDRAME et al., 2016, ROCHA et 
al., 2016, SILVA et al., 2016).

Notadamente, em função da localização geográfica do Distrito Federal, é relevante destacar as prevalências encontradas por Rocha et al. (2016), no estrato 2 do estado de Goiás, que abrange as regiões sul e sudeste do Estado, onde está inserido o quadrilátero correspondente ao território do Distrito Federal. Nestas regiões, com predomínio de rebanhos leiteiros, a tuberculose mostrou-se fortemente concentrada, com prevalências de rebanho de 8,67\% [IC 95\%: 5,73-12,74] e de animais iguais a 0,9\% [IC 95\%: 0,21-1,58] em fêmeas adultas. Ressalta-se igualmente as prevalências da doença registradas em Minas Gerais (BELCHIOR et al., 2016), em estudo realizado em 1999, nas regiões do Alto Paranaíba e Sul/Sudoeste, contíguas às regiões sul e sudeste de Goiás, respectivamente, de 9,66\% [IC 95\%: 5,73-15,01] e 7,17\% [IC95\%: 4,31-11,10] em rebanhos. Em novo estudo realizado em 2013, os resultados mantiveram-se estatisticamente compatíveis com o primeiro, sendo as prevalências em rebanho estimadas em 4,24\% [IC 95\%: 1,78-6,70] para o Alto Paranaíba e $6.77 \%$ [IC 95\%: 3,90-9,65] para o Sul/Sudoeste. Estas regiões, com prevalências superiores às registradas neste estudo, destacam-se nacionalmente como importantes bacias leiteiras, concentram um grande número de indústrias de lácteos e mantêm estreito vínculo comercial com o Distrito Federal, tanto de animais quanto de produtos.

O modelo analítico indicou o resfriamento de leite nas propriedades como fator de risco para a tuberculose bovina no Distrito Federal. Esta associação estatística encontrada não estabelece relação de causalidade, apenas apresenta o processo de resfriamento de leite como um indicativo da tipologia produtiva e do nível de tecnologia empregado pelas propriedades leiteiras amostradas. Das 45 propriedades que resfriavam leite, 77,8\% dedicavam-se exclusivamente à produção leiteira, $91,1 \%$ criavam os animais em regime confinado ou semiconfinado, 82,2\% possuíam rebanhos com mais de 15 fêmeas adultas e 86,7\% com mais de 15 vacas em lactação, 55,6\% faziam mais de duas ordenhas diárias e 62,2\% possuíam ordenhadeira mecânica, características compatíveis com propriedades que possuem rebanhos maiores e que adotam graus diferenciados de tecnologia na produção. De acordo com Perez et al. (2002), Elias et al. (2008), Humblet et al. (2009) e Belchior et al. (2016), propriedades com nível de tecnologia mais elevado tendem para sistemas de produção do tipo intensivo, normalmente relacionado aos sistemas de criação confinado ou semiconfinado, estes apontados como fatores de risco por favorecerem maior oportunidade de contato entre animais infectados e susceptíveis, aumentando assim o risco de transmissão da tuberculose bovina por via aerógena. 
Belchior et al. (2016), em Minas Gerais, observou prevalências mais altas para tuberculose bovina em propriedades produtoras de leite com algum grau de mecanização da ordenha e de tecnificação da produção. Outros estudos, utilizando a mesma metodologia analítica, conduzidos no Paraná (SILVA et al., 2016), Bahia (BAHIENSE et al., 2016), Rondônia (VENDRAME et al., 2016), Mato Grosso (NESPOLI et al., 2016) e Santa Catarina (VELOSO et al., 2016), também relataram maior ocorrência de tuberculose bovina associada a rebanhos de propriedades produtoras de leite com graus diferenciados de tecnologia aplicados à produção, com destaque para a utilização de ordenhadeira mecânica, o que é coerente com o encontrado neste estudo, porém associado a outra variável explicativa, representada pelo resfriamento de leite, que conduz a conclusão equivalente.

O resfriamento consiste na conservação do leite ordenhado em baixas temperaturas em tanques de refrigeração por expansão direta ou em tanques de imersão do latão em água gelada, devendo ser recolhido e transportado por caminhões-tanque isotérmicos até o laticínio. Estes procedimentos estão regulamentados pela Instrução Normativa $n^{\circ}$ 62/2011, do Mapa (BRASIL, 2011). A refrigeração e o transporte a granel possibilita uma grande redução de custos que beneficia os produtores com a redução dos custos do frete, flexibilidade nos horários de ordenha e aumento de produtividade; as indústrias, com a redução dos custos com insumos e mão de obra para limpeza dos latões; e os consumidores, com o incremento na qualidade do produto (RIBEIRO \& TEIXEIRA, 2000; PEREIRA, 2011). No entanto, os custos de implantação e manutenção do sistema de refrigeração na fazenda ainda são elevados. Brito \& Diniz (2005) argumentam que do ponto de vista financeiro, os investimentos em tanques de resfriamento de 250 litros (de menor capacidade do mercado), não são recomendáveis, além do fato de que com menos de 50 litros de leite/dia não há lucratividade suficiente que remunere o gasto necessário para adquirir um tanque de refrigeração. Para a pequena produção, a legislação permite a utilização de tanques de expansão comunitários (BRASIL, 2011). Neste contexto, pode-se inferir quanto a uma tecnologia mais presente em propriedades de maior produção leiteira, associada a rebanhos maiores e mais especializados que tendem para sistema de produção intensivo e criação em regime confinado ou semiconfinado, o que favorece maior contato entre animais infectados e susceptíveis, aumentando assim o risco de transmissão da tuberculose bovina pela via aerógena.

À exceção do resfriamento de leite, não foi encontrada associação estatística entre a ocorrência de tuberculose bovina e as demais variáveis reconhecidas por representarem 
mecanismos de propagação da doença entre rebanhos, destacando-se: aluguel de pasto, trânsito animal, presença de pastagem em comum com outras propriedades, compartilhamento de água e bebedouros com outras propriedades, presença de animais silvestres de vida livre e existência de áreas de concentração de animais ou de pouso de boiadas em trânsito nas propriedades. Tal resultado, entretanto, pode ser consequente a: (a) baixo poder discriminante destas variáveis na população estudada; (b) baixo quantitativo de focos detectados - de acordo com Dohoo, Martin \& Stryhn (2010), o reduzido número de casos positivos, que pode afetar o poder dos testes estatísticos.

A propósito das baixas prevalências encontradas e do fator de risco identificado para tuberculose bovina neste estudo, apontando para as propriedades de produção leiteira mais tecnificadas, é relevante destacar alguns aspectos de natureza técnica e social que circunstanciam a atividade de produção de leite no DF e que podem contribuir para avanços no controle e erradicação da tuberculose bovina nesta unidade federativa.

De acordo com Luz (2014), os produtores rurais de leite no DF possuem sistemas de produção bastante diversificados em suas unidades produtivas. Os objetivos variam desde a alternativa de lazer, reserva de valor de terras e animais, alimentação complementar e renda em vários níveis e interesses.

A produção leiteira no DF, em 2007, segundo a EMATER/DF, era de 35.635 .900 de litros por ano e o consumo agregado, em litros, situava-se em 161.450.402, havendo 77,92\% em déficit de consumo representado pelo volume de 125.814.502 litros (BRASÍLIA, 2008). Apesar de haver demanda por consumo maior que o volume produzido, a produção leiteira anual do DF em 2011 diminuiu em relação aos anos anteriores para 30 milhões de litros de leite fluido (IBGE, 2013).

O Governo local atua na cadeia produtiva do leite como comprador de grande parte da produção, por meio de programas institucionais próprios e de outros em parceria com o Governo Federal. Além do DF, adquire leite e derivados em municípios vizinhos dos Estados de Goiás e Minas Gerais, para o fornecimento a entidades filantrópicas, famílias de baixa renda e a estudantes da rede pública distrital de ensino fundamental (LUZ, 2014). Além disso, a título de incentivo e fomento, são disponibilizados aos produtores assistência técnica e recursos creditícios diferenciados para desenvolvimento de projetos na atividade, bem como recursos financeiros específicos para indenizações em casos de sacrifício sanitário de animais, oriundos de Fundos Públicos do Tesouro Distrital (SEAGRI/DF 2016). Este cenário, associado à baixa prevalência territorial da tuberculose bovina encontrada neste estudo e ao 
pequeno número de rebanhos e de animais, permite inferir sobre um ambiente favorável à implementação de um programa de certificação de propriedades livres de tuberculose bovina no âmbito do programa sanitário, seja como medida estratégica voluntária por meio de incentivos junto às indústrias de laticínios ou condicionada à liberação de créditos para projetos de pecuária leiteira, fornecimento de matéria prima para programas institucionais de alimentação e indenização de animais.

Uma implicação direta frente aos resultados obtidos neste estudo diz respeito à Instrução Normativa $n^{\circ}$ 19, de 10 de outubro de 2016, do Mapa, publicada no Diário Oficial da União (DOU) em 3 de novembro de 2016, que estabelece o novo Regulamento Técnico do Programa Nacional de Controle e Erradicação da Brucelose e da Tuberculose Animal (PNCEBT) e a Classificação das Unidades da Federação de acordo com o grau de risco para as doenças brucelose e tuberculose, assim como a definição de procedimentos de defesa sanitária animal a serem adotados de acordo com a classificação (BRASIL, 2016).

Considerando o grau de risco para a tuberculose animal, as UFs serão classificadas pelo Departamento de Saúde Animal (DSA), do Mapa, conforme a tabela 9 em classes de "A" a "E", determinadas pelas prevalências estimadas por meio de estudos padronizados e, níveis de " 0 " a "3", levando em consideração a execução das ações de defesa sanitária animal propostas em plano de ação elaborado pelo serviço veterinário estadual e aprovado pelo DSA, que contemple as medidas estabelecidas pelo PNCEBT (BRASIL, 2016).

Tabela 9. Tabela de classificação de risco das UFs para tuberculose bovina e bubalina

\begin{tabular}{lccccc}
\hline & & \multicolumn{4}{c}{ Nível } \\
\cline { 3 - 6 } $\begin{array}{c}\text { Prevalência de } \\
\text { Focos }(\%)\end{array}$ & Classe & \multicolumn{4}{c}{ Qualidade da execução das ações } \\
\cline { 3 - 6 } & & Inicial & Baixa & Média & Alta \\
\hline 2 & $\mathrm{~A}$ & 0 & 1 & 2 & 3 \\
$\geq 2<3$ & $\mathrm{~B}$ & 0 & 1 & 2 & 3 \\
$\geq 3<6$ & $\mathrm{C}$ & 0 & 1 & 2 & 3 \\
$\geq 6$ & $\mathrm{D}$ & 0 & 1 & 2 & 3 \\
Desconhecida & $\mathrm{E}$ & 0 & 0 & 0 & 0 \\
\hline
\end{tabular}

E0 - Risco desconhecido; D0, D1, D2 e D3 - Risco alto; C0, C1, C2 e C3 - Risco médio B0, B1, B2 - Risco baixo; B3, A0, A1 e A2 - Risco muito baixo; A3 - Risco desprezível Fonte: DOU no 211, Seção I, pg. 10, 2016.

Pode-se concluir, com base nos critérios de classificação estabelecidos pela nova 
legislação que rege o PNCEBT e na prevalência de focos estimada neste estudo, que o Distrito Federal enquadra-se na classe "C", de "Risco Médio" para tuberculose bovina, com nível de qualidade de execução das ações ainda por avaliar e definir. Esta classificação implica na adoção de medidas em caráter obrigatório, especialmente a vigilância para detecção e saneamento dos focos detectados pelo serviço veterinário oficial para evolução no controle e erradicação da tuberculose nesta Unidade Federativa (BRASIL, 2016).

A tuberculose bovina encontra-se distribuída em toda extensão territorial do Distrito Federal, com tendência a concentrar-se em rebanhos maiores, de produção leiteira e que incorporam algum grau de tecnologia à produção. As prevalências da enfermidade, no entanto, são baixas, tanto em rebanhos quanto em animais, compatíveis com a implementação de medidas estratégicas que visem sua erradicação nesta Unidade Federativa, sobretudo direcionadas a explorações leiteiras de maior rendimento. A adoção de medidas de vigilância, especialmente o monitoramento e aperfeiçoamento da inspeção de carcaças em abatedouro, sobretudo de animais de descarte, com o acompanhamento dos casos notificados, pode contribuir para a detecção e saneamento de focos e para a evolução no controle e erradicação da doença no Distrito Federal.

A realização de estudos do tipo caso-controle pode ser mais apropriada ao cenário epidemiológico atual da tuberculose bovina no DF, buscando caracterizar melhor os mecanismos de propagação da doença, incluindo modalidades comerciais, circulação de animais e de seus produtos, de forma a estimar riscos que fundamentarão o planejamento e a adoção de medidas estratégicas associadas às atividades de vigilância.

\section{REFERÊNCIAS BIBLIOGRÁFICAS}

ALFINITO, J.W. \& OLIVEIRA, F.R. Estudo Epidemiológico da Tuberculose Bovina na Ilha de Marajó. In: CONGRESSO BRASILEIRO DE MEDICINA VETERINÁRIA, 20, 1986, Cuiabá. Anais. Cuiabá: Sociedade Matogrossense de Medicina Veterinária, 1986. p. 216217.

BAHIENSE, L., BAVIA, M.E., AMAKU, M., DIAS, R.A., GRISI FILHO, J.H.H., FERREIRA, F., TELLES, E.O., GONÇALVES, V.S.P., HEINEMANN, M.B., FERREIRA NETO, J.S. Prevalence and risk factors for bovine tuberculosis in the State of Bahia, Brazil. Semina: Ciências Agrárias, Londrina, v. 37, n. 5, suplemento 2, p. 3549-3560, 2016.

BELCHIOR, A. P. C., LOPES, L. B., GONÇALVES, V. S. P., LEITE, R. C. Prevalence and risk factors for bovine tuberculosis in Minas Gerais State, Brazil. Tropical Animal Health and Production, Edinburg, v. 48, n.2, p. 373-78, 2016. 
BRASIL, Ministério da Agricultura, Pecuária e Abastecimento. Instrução Normativa $\mathbf{n}^{\mathbf{0}}$ 62, de 29 de dezembro de 2011. Aprova o Regulamento Técnico de Produção, Identidade e Qualidade do Leite tipo A, o Regulamento Técnico de Identidade e Qualidade de Leite Cru Refrigerado, o Regulamento Técnico de Identidade e Qualidade de Leite Pasteurizado e o Regulamento Técnico da Coleta de Leite Cru Refrigerado e seu Transporte a Granel, Diário Oficial da União, Brasília, 30/12/2011 - Seção 1.

BRASIL. Ministério da Agricultura Pecuária e Abastecimento. Manual Técnico do Programa Nacional de Controle e Erradicação da Brucelose e da Tuberculose Animal. Brasília, DF: Mapa, Secretaria de Defesa Agropecuária, 2006. 188p.

BRASIL, Ministério da Agricultura, Pecuária e Abastecimento. Instrução Normativa $\mathbf{n}^{\mathbf{0}}$ 19, de 10 de outubro de 2016. Estabelece o Regulamento Técnico do Programa Nacional de Controle e Erradicação da Brucelose e da Tuberculose Animal e a Classificação das Unidades da Federação de acordo com o grau de risco para as doenças brucelose e tuberculose. Mapa, Secretaria de Defesa Agropecuária. Diário Oficial da União, Brasília, 3 de novembro de 2016, Seção I, p. 7-10.

BRITO, M.A.V.P., DINIZ, F.H. Tanques comunitários: Qualidade aos pequenos. Balde Branco, São Paulo, n.489A, p.40-42, 2005.

CASTRO, D. Prevalência de Bovinos Reagentes à Prova Tuberculínica no Município de Uberaba, MG, 1978. 1979. (Mestrado em Medicina Veterinária Preventiva) - Escola de Veterinária, Universidade Federal de Minas Gerais, Belo Horizonte.

CODEPLAN - Companhia de Planejamento do Distrito Federal - Secretaria de Estado de Planejamento e Orçamento do Distrito Federal (SEPLAN) - Relatório do Produto Interno Distrito Federal 2012, Brasília-DF, nov. 2014.

DIAS, R.A., STANOJLOVIC, F.M.U., BELCHIOR, A.P.C., FERREIRA, F.S., GONÇALVES, R.C., ELIAS, K, HUSSEIN, D., ASSEGED, B., WONDWOSSEN, T., GEBEYEHU, M. Status of bovine tuberculosis in Addis Ababa dairy farms. Revue Scientifique et Technique de l'Office Internacional des Epizooties, v. 27, n. 3, p. 915-923, 2008 .

DIAS, R.A., STANOJLOVIC, F. M. U, BELCHIOR, A.P.C., FERREIRA, R. S, GONÇALVES, R, C., BARÃO, R. S. C., SOUSA, P. R., SANTOS, A.M.A., Marcos AMAKU1, FERREIRA, F., TELLES, E.O., GRISI FILHO, J. H. H., GONÇALVES, V.S.P., HEINEMANN, M. B, José Soares Ferreira NETO, J. S. F. Semina: Ciências Agrárias, Londrina, v. 37, n. 5, suplemento 2, p. 3673-3684, 2016.

EMATER-DF (Empresa de Assistência Técnica e Extensão Rural do Distrito Federal) e outros. Plano Executivo de Desenvolvimento Sustentável da Cadeia Produtiva da Pecuária Leiteira no Distrito Federal 2008/2012. Brasília, 2008. 52p.

ESRI - Environmental Systems Research Institut, 2012. ArcGIS Desktop Software. 
FAO - Food and Agriculture Organization of the United Nations. Animal Production and Health Division. Bovine tuberculosis at the animal-human-ecosystem interface. EMPRES Transboundary Animal Diseases Bulletin, n. 40, 11 p., 2012.

FRANCISCO, P. F. C. Caracterização do Ambiente Pecuário e Análise de Prevalência de Brucelose e Tuberculose Bovinas no Distrito Federal. Monografia FAV-UnB. Brasília, 2008. 36p.

GALVIS, J. O. A, GRISI-FILHO, J.H.H., COSTA, D., SAID, A.L.P.R., AMAKU, M., DIAS, R. A., FERREIRA, F., GONÇALVES, V.S.P. HEINEMANN, M .B., TELLES, E. O., NETO, J. S. F. Prevalence and risk factors for bovine tuberculosis in the State of Espírito Santo, Brazil. Semina: Ciências Agrárias, Londrina, v. 37, n. 5, suplemento 2, p. 3567-3578, 2016

GUEDES, I.B., BOTTENE, I.F.N., MONTEIRO, L.A.R.C., LEAL FILHO, J.M., HEINEMANN, M.B., AMAKU, M., GRISI FILHO, J.H.H., DIAS, R.A., FERREIRA, F., TELLES, E.O., GONÇALVES, V.S.P., FERREIRA NETO, J.S. Prevalence and risk factors for bovine tuberculosis in the State of Mato Grosso do Sul, Brazil. Semina: Ciências Agrárias, Londrina, v. 37, n. 5, suplemento 2, p. 3579-3588, 2016.

H. LAMINE-KHEMIRI, R. MARTINEZ, W. L. GARCIA-JIMENEZ et al.., "Genotypic characterization by spoligotyping and VNTR typing of Mycobacterium bovis and Mycobacterium caprae isolates from cattle of Tunisia", Tropical Animal Health and Production, vol. 46, no. 2, pp. 305-311, 2014.

HUMBLET, M. F., BOSCHIROLI, M. L., SAEGERMAN, C. Classification of worldwide bovine tuberculosis risk factors in cattle: a stratified approach. Veterinary Research, Les Ulis, FR, v. 40, n. 5, p.50, 2009.

IBGE - Instituto Brasileiro de Geografia e Estatística - Cidades - Informações sobre os municípios. Disponível em http://www.cidades.ibge.gov.br/xtras/home.php, acessado em 30/09/2016.

LAENDER, F. C. Prevalência de bovinos reagentes à prova de tuberculina no município de Pedro Leopoldo, MG, 1977. 1978. (Mestrado em Medicina Veterinária Preventiva) Escola de Veterinária, Universidade Federal de Minas Gerais, Belo Horizonte.

LIMA, P.B., NASCIMENTO, D.L., ALMEIDA, E.C., PONTUAL, K.A.Q., AMAKU, M., DIAS, R.A., FERREIRA, F., GONÇALVES, V.S.P., TELLES, E.O., GRISI FILHO, J.H.H., HEINEMANN, M.B., SILVA, J.C.R., FERREIRA NETO, J.S. Epidemiological characterization of bovine tuberculosis in the State of Pernambuco, Brazil. Semina: Ciências Agrárias, Londrina, v. 37, n. 5, suplemento 2, p. 3601-3610, 2016.

LÔBO J.R. 2008. Análise custo-benefício da certificação de propriedades livres de tuberculose bovina. Dissertação de Mestrado em Agronegócios, Universidade de Brasília, Brasília, DF. 84p. 
LUZ, C. C. V. da. Fatores que afetam a inovação tecnológica de sistemas produtivos de produtores familiares na cadeia produtiva leiteira do Distrito Federal. 2014. $192 \mathrm{f}$. Dissertação (Mestrado em Agronegócio) - Faculdade de Agronomia e Medicina Veterinária, Universidade de Brasília, Brasília, 2014.

MANUAL DE PROCEDIMENTOS - Estudo Epidemiológico da Brucelose e Tuberculose em Bovinos - Programa Nacional de Controle e Erradicação da Brucelose e da Tuberculose Animal (PNCEBT) - Ministério da Agricultura, Pecuária e Abastecimento, 2014. 18p.

NÉSPOLI, J.M.B., NEGREIROS, R.L., AMAKU, M., DIAS, R.A., FERREIRA, F., TELLES, E.O., HEINEMANN, M.B., GRISI FILHO, J.H.H., GONÇALVES, V.S.P., FERREIRA NETO, J.S. Epidemiological situation of bovine tuberculosis in the state of Mato Grosso, Brazil. Semina: Ciências Agrárias, Londrina, v. 37, n. 5, suplemento 2, p. 3589$3600,2016$.

OLIVEIRA, I. A. S., MELO, H. P. C., CAMARA, A., DIAS, R. V. C., SOTO-BLANCO, B. Prevalência de tuberculose no rebanho bovino de Mossoró, Rio Grande do Norte. Brazilian Journal of Veterinary Research and Animal Science, São Paulo, v. 44, n. 6, p. 395-400, 2007.

OLIVEIRA, V. M., FONSECA, A. H., PEREIRA, M. J. S., CARNEIRO, A. V., JESUS, V. L. T. ALVES, P. A. M. Análise retrospectiva dos fatores associados à distribuição da tuberculose bovina no estado do Rio de Janeiro. Arquivo Brasileiro de Medicina Veterinária e Zootecnia, Belo Horizonte, v. 60, n. 3. p. 574-579, 2008.

PEREZ, A. M, WARD, M.P. ARMANDO, CHARMANDARIAN, A., RITACCO,V. Simulation model of within-herd transmission of bovine tuberculosis in Argentine dairy herds. Preventive Veterinary Medicine, Amsterdam, 54 (2002), 361-372.

PEREIRA, D. A. Fatores Impactantes na Qualidade do Leite de Tanques Comunitários na Microrregião de Juiz de Fora - MG. Dissertação (Mestrado Profissionalizante em Ciência e Tecnologia do Leite e Derivados) - Universidade Federal de Juiz de Fora, 2011.

POLETTO, ROSANGELA et al. Prevalência de tuberculose, brucelose e infecção víricas em bovinos leiteiros do município de Passo Fundo, RS. Ciência Rural, Santa Maria v.34,

QUEIROZ, M.R., GROFF, A.C.M., SILVA, N.S., GRISI FILHO, J.H.H., AMAKU, M., DIAS, R.A., TELLES, E.O., HEINEMANN, M.B., FERREIRA NETO, J.S., GONÇALVES, V.S.P. FERREIRA, F. Epidemiological situation of bovine tuberculosis in the State of Rio Grande do Sul, Brazil. Semina: Ciências Agrárias, Londrina, v. 37, n. 5, suplemento 2, p. 3647-3658, 2016

RIBEIRO, L.A., GONÇALVES, V.S.P., FRANCISCO, P.F.C., MOTA, A.L.A.A., NASCIMENTO, G.T., LICURGO, J.B., FERREIRA, F., GRISI FILHO, J.H.H., FERREIRA NETO, J.S., AMAKU, M., DIAS, R.A., TELLES, E.O., HEINEMANN, M.B., BORGES, J.R.J. Epidemiological situation of bovine tuberculosis in the Federal District, Brazil. Semina: Ciências Agrárias, Londrina, v. 37, n. 5, suplemento 2, p. 3561-3566, 2016. 
RIBEIRO, M.T. \& TEIXEIRA, S.R.L. Qualidade do leite em tanques de expansão individuais ou comunitários. Glória Rural, Rio de Janeiro, v.3, n.38, p.28-35, 2000.

ROCHA, W.V., JAYME, V.S., GONÇALVES, V.S.P., BRITO, W.M.E.D., PIRES, G.R.C, MOTA, A.L.A.A., GRISI FILHO, J.H.H, DIAS, R.A., AMAKU, M., TELLES, E.O., HEINEMANN, M.B., FERREIRA, F., FERREIRA NETO, J.S. Epidemiological situation of bovine tuberculosis in the State of Goiás, Brazil. Semina: Ciências Agrárias, Londrina, v. 37, n. 5, suplemento 2, p. 3625-3638, 2016.

SEAGRI-DF - Secretaria de Estado de Agricultura e Desenvolvimento Rural do Distrito Federal - Dados de vigilância sanitária animal disponibilizados pela Diretoria de Sanidade Agropecuária e Fiscalização. Brasília-DF, 2016.

STATACORP. 2011. Stata: Release 12. Statistical Software. College Station, TX: StataCorp LP.

VELOSO, F.P., BAUNGARTEN, K.D., MOTA, A.L.A.A., FERREIRA, F., FERREIRA NETO, J.S., GRISI FILHO, J.H.H., DIAS, R.A., AMAKU, M., TELLES, E.O., HEINEMANN, M.B., GONÇALVES, V.S.P. Prevalence and herd-level risk factors of bovine tuberculosis in the State of Santa Catarina, Brazil. Semina: Ciências Agrárias, Londrina, v. 37, n. 5, suplemento 2, p. 3659-3672, 2016.

VENDRAME, F.B., AMAKU, M., FERREIRA, F., TELLES, E.O., GRISI FILHO, J.H.H., GONÇALVES, V.S.P., HEINEMANN, M.B., FERREIRA NETO, J.S.; DIAS, R.A. Epidemiologic characterization of bovine tuberculosis in the State of Rondonia, Brazil. Semina: Ciências Agrárias, Londrina, v. 37, n. 5, suplemento 2, p. 3639-3646, 2016.

WHO, “World Health Organization global TB report (2014): Tuberculosis (TB)," Fact sheet 104, WHO, Geneva, Switzerland, 2014, http://www.who.int/mediacentre/factsheets/fs104/en/. 